\title{
Article
}

\section{Workplace Flexibility Practices in SMEs: Relationship with Performance via Redundancies, Absenteeism, and Financial Turnover}

Whyman, Philip B and Petrescu, Alina

Available at http://clok.uclan.ac.uk/7088/

Whyman, Philip B ORCID: 0000-0002-3926-1019 and Petrescu, Alina ORCID: 0000-0002-7459-7714 (2015) Workplace Flexibility Practices in SMEs: Relationship with Performance via Redundancies, Absenteeism, and Financial Turnover. Journal of Small Business Management, 53 (4). pp. 1097-1126. ISSN $1540-627 x$

It is advisable to refer to the publisher's version if you intend to cite from the work.

For more information about UCLan's research in this area go to http://www.uclan.ac.uk/researchgroups/ and search for <name of research Group>.

For information about Research generally at UCLan please go to http://www.uclan.ac.uk/research/

All outputs in CLoK are protected by Intellectual Property Rights law, including Copyright law. Copyright, IPR and Moral Rights for the works on this site are retained by the individual authors and/or other copyright owners. Terms and conditions for use of this material are defined in the policies page. 


\title{
Workplace flexibility practices in SMEs: Relationship with performance via redundancies, absenteeism and financial turnover
}

\author{
by Philip B. Whyman and Alina I. Petrescu
}

This workplace flexibility study uses primary data on private sector Small and Medium Enterprises (SMEs) in Lancashire, United Kingdom, collected in 2009 during the recent 'credit crunch' recession. Key features include: (a) objective measures of SME performance; (b) a focus on the previously relatively neglected relationship between workplace flexibility practices (WFPs) and three SME performance indicators, namely redundancies, absenteeism and financial turnover; and (c) a timely contribution to research on SMEs. Numerical, functional and cost WFPs analyses, via zero-inflated Poisson and linear regressions, control for SME and market characteristics. Despite SMEs having limited resources, the results show a significant section of SMEs to be innovative and entrepreneurial organisations, embracing advancements in employment relations regarding employee discretion, training, participative working arrangements and/or job security. Moreover, results indicate that WFPs have the potential to assist SMEs in responding to periods of constrained demand. Flexitime and job sharing are associated with low permanent-employee redundancies. Training, job security and family friendly practices relate to low absenteeism with reductions of up to six annual days per worker. Job security and profit-related pay are associated with high financial turnover. Staff pay-freeze links with high financial turnover, but to the detriment of redundancies and absenteeism, while management pay-cuts or management pay-freeze relate to low financial turnover. On a cautionary note, spending cuts, often enforced by policy makers, may be of limited benefit to SMEs, and thus other approaches would appear more fruitful.

\section{Introduction: Motivation for Researching Workplace Flexibility in SMEs}

Conditions of weak demand are, by definition, problematic for firms, conflicting with organisational interests to maintain production and protect human capital assets. One potential response to recessionary pressures relates to an increase in workplace flexibility. This approach might enable firms to adapt to new market conditions whilst increasing organisational efficiency. It may also have particular resonance for small and medium-sized enterprises (SMEs), due to their limited scale and resources. In Britain, SMEs represent 99.9 percent of companies, account for 59.2 percent of private sector employment and 51.5 percent of private sector turnover (BERR 2008), so their success in adapting to new market conditions is of vital importance to the future of the whole economy. Yet, surprisingly, SME research remains under-developed (Chandler and McEvoy 2000; Tocher and Rutherford 2009).

There is little consensus over an exact definition of workplace flexibility practices (WFPs), which is unexpected when taking into account the wide interest in their utilisation from government, policy makers and practitioners.

\footnotetext{
*The authors are grateful to the Lancashire Business School, UCLan (UK) for the financial support given to this research project (Report Award Number LBS-080922). Moreover, we acknowledge the Preston City Council as the originator and the distributor of the Central Lancashire Business Directory 2009 data, and we wish to thank the North and Western Lancashire Chamber of Commerce, and the Central Lancashire branch of the Federation of Small Businesses, who supported the research by name and logo. None of these organisations bears any responsibility for the authors' analysis and interpretations of the data. Furthermore, we thank Michael Bowerman who worked dutifully as intern student assisting this project. The authors also wish to acknowledge the two anonymous reviewers who commented on a previous version of this paper. We thank them for their valuable suggestions.

Philip B. Whyman is Professor of Economics and Director of the Institute for Economic and Business Research (LIEBR) at Lancashire Business School, University of Central Lancashire.

Alina Ileana Petrescu is Research Fellow in Labour Economics and member of the Institute for Economic and Business Research (LIEBR) at Lancashire Business School, University of Central Lancashire.

Address correspondence to: Dr. Alina I. Petrescu, Lancashire Business School, University of Central Lancashire, Preston, PR1 2HE, United Kingdom. E-mail: APetrescu@uclan.ac.uk.

Topics of Small Business Research: Small Business Strategy and Organization; Small Business Policy and Economics.
} 
Definitions may also vary according to whether WFPs are conceptualised mainly from the firm's or employees' perspective (Hill et al. 2008), with recent literature pointing towards the importance of analysing both perspectives in order to understand whether and which WFPs may lead to mutual gains (Whyman and Petrescu, forthcoming). ${ }^{1}$ For the purpose of this study, WFPs can be loosely defined to encompass both employee and organisational perspectives, as a large number of work arrangements and patterns aimed to enable employees and employers to adjust corporate activities in order to adapt to the demands of the working life and the economic climate. Originating in the seminal work of Atkinson (1984), the classification of WFPs distinguishes among: numerical flexibility, described as the adjustment of the number of workers or of their working time; functional flexibility described as the adjustment of the job content or of the ways in which employees are expected to perform their jobs; and cost or wage flexibility described as the adjustment of the ways in which pay is decided. Typical examples of practices falling in the numerical flexibility category are non-standard contracts such as part-time working, working from home, shiftworking, flexi-time or job sharing. Functional flexibility practices usually include training, job enrichment, team work, or allowing employees job autonomy via having a say in the design or content of their job. Cost flexibility describes various forms of setting pay systems such as through negotiations with trade unions, profit-related payments, merit pay or payment by results.

The use of flexible working arrangements has been illustrated during the recent British economic recession, when it appears that many firms view WFPs as an essential part of a modern employment relationship and a source of competitive advantage; for instance in terms of the speed of adapting to the economic climate (CBI 2010). Firms faced with difficult economic conditions have increasingly turned to WFPs to resolve competitive pressures and/or to reduce costs and remain solvent. For example, in Britain, by July 2009, it was reported that more than two thirds of firms had made, intended to make, or considered making, changes to their working patterns via higher use of flexible working (CBI 2009). Evidence during this period points to organisations shifting their practices dramatically in favour of adopting flexible programmes, including reduced pay or pay-freezes, reduced hours, or increased reliance on casual contracts (CBI 2009). Industry surveys in Britain report on WFPs proving their "worth again during the recession", and that "the unprecedented co-operation between employers and employees through measures such as short-time working, hiring freezes and moderation in pay has helped to minimise job losses" (CBI 2010, p. 1).

This study, therefore, focuses on the incidence and use of WFPs by SMEs operating within recessionary conditions, and utilises objective measures of performance; all aspects generally under-represented in the literature. Its

\footnotetext{
${ }^{1}$ A notable trend in the literature is to define the concept of workplace flexibility in relation to the scope of the study. For instance, Hill et al. (2008, p. 152) define flexibility from an employee perspective: "the ability of workers to make choices influencing when, where, and for how long they engage in work-related tasks". In contrast, Martinez-Sanchez et al. (2007, p. 648) use an organisational perspective in their definition: "we define workplace flexibility as the ability to address changes in labour organization in the workplace". Or, the definition of workplace flexibility proposed in this paper claims the middle ground, being inclusive of both perspectives.
} 
broad aim is to identify the WFPs used by SMEs, whilst assessing how these can best equip SMEs to deal with difficult economic conditions. Fieldwork involved conducting primary data collection during summer 2009, a period of time corresponding to the height of the recent economic recession in Britain, on a geographically-focused representative sample of Lancashire (UK) based SMEs. The new data brought to light here allows some of the first insights into the extent of use of WFPs in these SMEs during recession conditions. Results are useful to SMEs suffering from pressures to make redundancies, to minimise absence and obtain high financial turnover during the recession, and are also relevant in the long run due to firms facing a difficult economic climate for the foreseeable future during a fragile post-recession recovery period. It is anticipated that findings can inform SME managers, public policy makers and practitioners of methods to reduce costs in the organisations surveyed, having potentially wider applicability.

\section{Literature, Theory, and Hypotheses}

\section{Addressing Literature Gaps: WFPs and SME Objectively-Measured Performance during Recession}

The literature on human resource management (HRM) and, more specifically, upon workplace flexibility practices

(WFPs) within SMEs, has been historically under-developed, as studies have tended to focus upon larger organisations, possibly due to their greater resources and accompanying specialisation in management functions, including the design and implementation of human resource strategies (Cassell et al. 2002; Chandler and McEvoy 2000; Deshpande and Golhar 1994; Georgiadis and Pitelis 2012; Matlay 2002; Tocher and Rutherford 2009). This research deficit has begun to be addressed (for example, Smith and Zagelmayer 2010; Tocher and Rutherford 2009) and this paper seeks to make a further contribution in this regard.

WFPs are generally discussed, within the literature, in the context of the high performance workplace practices (HPWPs) thesis, which holds that organisations may secure improved outcomes through utilisation of progressive elements of HRM strategy, seeking to create a motivated and committed workforce through providing employees with a greater sense of personal control and efficacy (Appelbaum et al. 2000; Berg et al. 2004; Glover and Butler 2012). Specific initiatives include the promotion of functional flexibility, multi-skilling, autonomous work teams, problemsolving groups (i.e. quality circles and suggestion schemes), induction and inter-personal skills training, team briefing, information disclosure and appraisal schemes, together with greater opportunities for self-management and/or employee participation in decision-making (Osterman 2000; Wood and de Menezes 1998; Wood et al. 2003).

There is some evidence, contained within the literature, that WFPs are perceived as helping to obtain a better work-life balance, which has the potential to reduce the incidence of accidents, grievances, stress and labour turnover, and increase job satisfaction and commitment (Origo and Pagani 2008). In relation to organisational benefits, family- 
friendly policies are found to facilitate a reduction in labour turnover and absenteeism (Barmby, Ercolani and Treble, 2004; Lusinyan and Bonato 2007). For employers, Lazear (1998) shows that the main reason to introduce new WFPs is to lower unit costs, expressed as a ration of wages to production costs. WFPs also appear to facilitate lower absenteeism, higher retention and lower retraining costs, which are desirable outcomes especially when businesses face an economic downturn (Dex and Smith 2002; Eaton 2003; Lusinyan and Bonato 2007). Related studies show that organisations with family-friendly policies are better at retaining employees even if the employees choosing to remain within the organisation do not use the policies themselves (Grover and Crooker 1995; Yanadori and Kato 2009). Organisations with good work-life balance appear to retain superior levels of employee commitment, loyalty and motivation, and hence have fewer problems recruiting and retaining talented, productive employees (Bloom and Van Reenen 2006a; Maxwell et al. 2007; Russell, O'Connell, and McGinnity 2009).

However, despite this array of evidence, the impact of HPWPs on various measures of corporate performance remains uncertain: the literature has not reliably established the theoretical ways or the HPWPs through which organisational performance can be obtained (Buller and McEvoy 2012; Guest 2011; Stavrou, Brewster, and Charalambous 2010; Thompson 2011; Whyman et al. 2009), or whether a mutual benefit or equitable distribution of gains may be secured (Kelly 2004; Upchurch et al. 2008; Whyman and Petrescu, 2013).

One aspect arising from the high performance and WFP literature is the importance of evaluating individual elements of a given programme of innovations both separately, but also in terms of their effectiveness as part of bundled implementation (Batt and Valcour 2003; Eaton 2003). Many studies focus upon individual aspects, or small bundles, of WFPs treated in isolation (Chandler and McEvoy 2000; Gray 2002), whereas this runs the risk of overlooking important links between their use and performance, whilst potentially omitting potential trade-offs between individual aspects of an overall programme (Whyman et al. 2009). Individual aspects may be complimentary or create dysfunctional outcomes if implemented simultaneously (Perry-Smith and Blum 2000). Moreover, studies that fail to distinguish between individual components of flexible working risk omitted variable bias (Robinson and Wilson 2006). Hence, this paper adopts a disaggregated approach to testing the effectiveness of flexibility initiatives.

A second area where the existing literature is weak pertains to how organisations, and particularly SMEs, innovate in their HRM practices in response to periods of recessionary conditions or crises, whether analysed from a contingent or universalistic perspective, and with learning driven by a manager-imposed agenda or by managers in partnership with their employees (see Bryson 1996; Buller and McEvoy 2012; Carmeli and Schaubroeck 2008; Evans, Harvey, and Turnbull 2012; Glover and Butler 2012; Spillan and Hough 2003; Tocher and Rutherford 2009; Whyman and Petrescu 2013). Like other firms, conditions of weaker market demand typically cause SMEs to consider pursuing 
cost reductions and/or higher performance. Yet, in contrast to larger firms, SMEs must fashion a response without the benefit provided by the degree of resources and management specialisation available to larger firms (Deshpande and Golhar 1994; Georgiadis and Pitelis 2012; Levy and Powell 1998). The use of human resource flexibility practices is different in SMEs than in larger firms due to the former having generally leaner and more unified organisational structures, differential patterns of ownership and fewer management changes (Golden 2009; Matlay 2002; Storey 2002). It has been suggested that SMEs might adopt a more informal, reactive and short-term view in their business strategies (Golden 2009; Matlay 2002; Storey 2002; Tocher and Rutherford 2009). Furthermore, they are also less likely to have the expertise and knowledge that enable larger companies to introduce WFPs (Dex and Scheibl 2001).

A third aspect where this paper seeks to contribute to the literature relates to its use of objective measures of performance. Whilst subjective data provides useful insights into actor motivations and perceptions, they can be criticised as potentially unreliable. ${ }^{2}$ A significant feature of this study is that the role of a relatively large number of WFPs can be assessed in relation to objectively-measured performance indicators in the respective SME. Specifically, the measures of performance used in the analysis have been obtained directly from SME respondents in the form of objective quantifications of redundancies, absenteeism and financial turnover at the level of the SME. The choice of corporate performance indicators aims to encapsulate some of the most difficult decisions faced by SMEs during a recession event, in order to assess which WFPs associate significantly with the implementation of: (1) cost-cutting via downsizing and in particular laying off permanent employees; (2) securing low levels of absenteeism; and (3) pursuing improved performance by maintaining or enhancing financial turnover.

\section{Theory and Hypotheses}

There is no generally accepted theory of WFPs (Whyman et al. 2009). Hence the theoretical proposition applied in this paper is to decompose flexibility into the three distinct numerical, functional and cost flexibility areas identified by Atkinson (1984). Primary data has been gathered to map WFPs onto these three flexibility areas, adopting a disaggregated model of flexibility (Whyman and Baimbridge 2006; Whyman et al. 2009). ${ }^{3}$

The rationale for the disaggregation of WFPs is that theoretically equivalent choices are available to firms in reaching corporate goals by substituting or complementing different types of WFPs. For instance, one or a combination of the following may lead to labour cost savings, be it in the form of lower wage bills or higher worker productivity: numerical WFPs via flexitime; functional WFPs via training or job enrichment; or cost WFPs via pay-

\footnotetext{
${ }^{2}$ Numerous studies use subjective performance indicators such as perceived general performance and perceived financial performance, or less quantifiable measures of performance including employee morale, organisational commitment, manager-rated organisational performance or job satisfaction (Dex and Scheibl 2001; DTI 2005; Giardini and Kabst 2008; Origo and Pagani 2008).

${ }^{3}$ Other decompositions of WFPs have been utilised in a number of studies examining aspects of flexibility (Caroli et al. 2010; Kalleberg 2001; Martinez-Sanchez et al. 2007; Origo and Pagani 2008; Van der Mer and Ringdal 2009).
} 
freezes and cuts, or individual performance related pay. Moreover, flexibility initiatives may have differential impact - some more powerful than others - so in this paper the possibility of trade-offs in impact between different practices can be examined. Thus, the disaggregation of WFPs addresses a gap in the literature where most studies assume that forms of flexibility are mutually exclusive and few assess a large number of WFPs simultaneously (Kalleberg 2001; Whyman et al. 2009).

This paper tests three hypotheses constructed on the shared view in the literature that numerical, functional and cost WFPs are expected to induce productivity and strengthen commitment from employees whose needs are better met in a flexible workplace. In essence, it is hypothesised that SMEs implementing WFPs might be associated with: (1) low redundancies as a measure of how well they manage their workforce; (2) low absenteeism as a measure of employees looking forward to taking an active part of a flexible workplace and not skiving; and (3) high financial turnover as a measure of SME competitiveness under recession. In view of the cross-sectional nature of the data available, it is stated that the expected relationships tested here are with regard to the association between an organisation's flexibility profile and its performance, as opposed to the impact of flexibility practices on performance. The latter could have only been proven if longitudinal data were available.

The first hypothesis is that WFPs support SME entrepreneurs in limiting the pressures that recession puts on workforce via downsizing. It would be expected that an efficient and innovative use of WFPs might relate to a low number of redundancies (Eaton 2003). This would be the case especially with regard to the number of permanent employees. According to the flexible firm 'core-periphery' theory, permanent ('core') employees would be less likely to be made redundant than non-standard ('periphery') employees, as the latter will often be used to provide a degree of organisational flexibility necessary to protect the 'core' workers from the vagaries of change (Atkinson 1984; Kalleberg 2001). Permanent employees might be expected, therefore, to receive a higher priority than the peripheral workforce, in terms of greater job security, training in firm specific knowledge, intra-firm career plans and opportunities of functional flexibility (Atkinson 1984). The assumption, similar to the one of internal labour markets theory (Doeringer and Piore 1971), is that, when offering permanent contracts to its workers, an organisation is then more committed to integrating these employees in its highly skilled workforce. Consequently, relative to nonpermanent workers, laying off core workers would be more costly if at least in terms of redundancy pay. It may also be relatively more damaging to workforce morale to experience core workforce redundancies. Another significant detrimental effect of redundancies is that they signal to outsiders that the organisation is facing major difficulties.

It is, moreover, hypothesised that WFPs are instrumental in creating a workplace climate beneficial to the organisation and the employee in terms of a wide variety of measures. For instance, as previously mentioned in the 
literature review in this paper, WFPs may lead to a better work-life balance, increases in job satisfaction and commitment, lower unit costs, easier recruitment and retention of talent, or higher employee productivity (Bloom and Van Reenen 2006a; Dex and Smith 2002; Eaton 2003; Lazear 1998; Lusinyan and Bonato 2007; Maxwell et al. 2007; Origo and Pagani 2008; Russell, O'Connell, and McGinnity 2009). Hence, retention should be relatively high in SMEs making an efficient use of WFPs, and organisational benefits should ensue as WFPs lead to lower labour turnover. Specifically with regard to retention, Kacmar et al. (2006) find that labour turnover has an impact on unit-level performance in terms of both sales and profit. Moreover, Dex and Smith (2002) also find that labour turnover is lower in companies that offer job sharing, flexitime, and working from home and help with childcare to their employees. Furthermore, achieving lower labour turnover may be easier for SMEs than for larger organisations. To this extent, the British Workplace Employment Relations Survey 2004 (WERS 2004) shows that SMEs are less likely than larger firms to have lost a quarter or more of the workforce in the previous twelve months: 27 percent of SMEs reported this fall in their workforce compared to 45 percent of larger organisations (Forth, Bewley, and Bryson 2006). ${ }^{4}$

Hypothesis 1: The use of WFPs (numerical, functional and cost flexibility practices) is associated with low levels of permanent employee redundancies.

The second hypothesis assumes that WFPs are conducive to a less absent workforce, for instance since employees are enabled to diminish the mismatch between their contractual and desired hours or work, maintain a better work-life balance, and do not need to take unnecessary time off work. Brown and Sessions (1996) have offered a seminal contribution to the theoretical and empirical analysis of absenteeism. Yet, studies of absenteeism have concentrated on its determinants, mainly individual characteristics, or the impact on absenteeism of institutional frameworks and employment regulation (see Drago and Wooden 1992; Frick and Malo 2008). Few studies have analysed the relationship between WFPs and absenteeism. Among the exceptions, a recent large scale empirical research project in Europe has found that WFPS can reduce substantially corporate levels of absence (Lusinyan and Bonato 2007). In Britain in particular, Barmby, Ercolani, and Treble (2004) report that the flexibility in the contractual hours of work is a more important factor in determining absence than even individual characteristics. The second hypothesis is:

Hypothesis 2: The use of WFPs (numerical, functional and cost flexibility practices) is associated with low levels of absenteeism.

The third hypothesis assumes that WFPs allow organisations to make an efficient use of their financial resources and be productive, based on the manifold benefits of utilising WFPs to the employee and employer highlighted in the literature on WFPs and on HPWPs. The assumptions are rooted in the human capital theory that a better skilled and

\footnotetext{
${ }^{4}$ The WERS 2004 is the fifth wave in a series of British surveys aimed to provide a nationally representative view of employment relations in British workplaces (DTI, 2005). For more information, visit www.wers2004.info/.
} 
more knowledgeable worker is a more productive worker (Becker 1964). Yet, due to the limited range of the literature, there is no clear understanding in firms in general, and in SMEs in particular, of which practices can be linked to corporate performance. Moreover, the literature does not always sufficiently disaggregate WFPs in order to test whether each individual aspect impacts productivity (exceptions include Whyman et al. forthcoming), but a few studies do indicate that a range of WFPs seem to be associated with productivity improvement. Of those studies which focus specifically on SMEs, using US data, Way (2002) finds that HPWPs leave labour productivity unaffected in small businesses, whilst in the UK, Maxwell et al. (2007) report that WFPs lead to positive impacts in recruitment and retention, enhanced employee relations, commitment and loyalty, but also to operational problems and administrative burdens. Yet, an internationally comparative study by Bloom and Van Reenen (2006a), drawing upon SME data from the USA, France, Germany and the UK, find that better work-life balance practices are significantly associated with higher productivity. One weakness with the few British studies of SMEs available, relates to their focus on the incidence of WFPs rather than a measure of the impact (Bacon and Hoque 2005; Cassell et al. 2002; Dex and Schreibl 2001; Matlay 2002). Motivated by the fragmented picture of extant research into SMEs' use of WFPs with regard to performance, this paper proposes to test the following third hypothesis:

Hypothesis 3: The use of WFPs (numerical, functional and cost flexibility practices) is associated with high levels of financial turnover.

\section{Data, Variables and Methodology Data}

Primary data is derived from a survey of managers of SMEs (with human resource responsibility) in the Lancashire region of the United Kingdom, conducted during August 2009, at the height of the recent 'credit crunch' economic recession. For the purpose of this paper, an SME is defined based on the official criteria established by the European Union as an organisation with fewer than 250 employees and financial turnover of less than 50 million euro (66.6 million US dollars) (European Union 2003; European Commission 2002). The initial contact information for firms was obtained from the Central Lancashire Business Directory 2008 - 09 (CLBD2008-09) collected by the Preston City Council. This was a voluntary geographically-defined dataset, providing such details as employment size and industrial categories, and contained in excess of 3,300 businesses, of which 2,053 were SMEs. National statistical estimates suggested that this captured 44 percent of the potential total population (ONS 2009). In terms of stratification by size, the CLBD 2008-09 sample was similar to the North-West region of the UK, although compared to the nation as a whole it did under-represent micro firms (70 percent as opposed to 88 percent in the UK) and over- 
represent small (23 percent as opposed to nine percent) and medium (seven percent as opposed to three percent) firms (BERR 2008).

Of the 2,053 SMEs in the targeted sample, a combination of e-mail and postal questionnaires were utilised, in an attempt to maximise response rates. A passcode allowed respondents the option of filling in the questionnaire online. The response rate achieved was 7.1 percent, corresponding to 147 SMEs, which was reduced to the usable sample of 135 SMEs, after discarding unusable entries due to missing observations. Allowing for well-known difficulties in SME data collection such as difficulty of access, small response rates or small number of observations, the size of the usable dataset sample can be considered as acceptable (Dillman 1999; Easterby-Smith, Thorpe, and Lowe 1993).

By size, 59 percent of the sample were micro-SMEs (employed fewer than 10 people), with 32 percent employing between 10 and 49 people and nine percent between 50 and 249 employees. The participant sample closely mirrored the CLBD 2008-09 population, hence data weighing was not considered necessary. Further descriptives for the 135 SMEs in the sample used in this paper can be summarised as follows. All SMEs were active in the private sector. Almost all SMEs (97 percent of the sample) were non-unionised workplaces, with the same proportion being independent as opposed to being part of a larger organisation. Two thirds of the sampled firms were family owned ${ }^{5}$, whilst for about a quarter of the sample, female staff represented a majority of the workforce. A third of the sampled firms had been in business for less than 10 years, with a similar proportion hiring workforces where more than a third of the employees had a university degree. Only 13 percent of respondent firms had a specialised human resources manager. In terms of the industry composition, a fifth of the sampled SMEs were active in the manufacturing sector. ${ }^{6}$

Two particular SME characteristics, namely ownership type and industry sector, may influence the spread of WFPs. For instance, Moshavi and Koch (2005) suggest surprisingly that family-owned firms are less likely to adopt family-friendly WFPs, Bloom and Van Reenen (2006b) associate a high proportion of the 'badly managed firms" to family ownership, while Woodland et al. (2003) reports that WFPs are more prevalent in the public than private sector. In view of these findings, our analysis of a private sector sample of mostly family-owned firms is likely to underestimate the incidence and usefulness of WFPs.

\section{Dependent Variables: SME Performance Indicators}

\footnotetext{
${ }^{5}$ Family-owned SMEs form a large proportion of SMEs in other countries too - see the study in US by Carlson, Upton, and Seaman (2006). ${ }^{6}$ Since their economic profile and strategies would be too specific and different than for the rest of organisations in the sample, SMEs from the following three sections based on the Standard Industrial Classification (SIC 2003) are excluded from the survey of Lancashire SMEs: Section A "Agriculture, Hunting and Forestry"; Section B "Fishing"; and Section C "Mining and Quarrying". This is in line with the sample definition restrictions observed in similar organisational research in Britain, such as the Workplace Employment Relations Survey (WIRS / WERS) series (see Bryson, Green, and Whitfield 2008).
} 
Redundancies, absenteeism and financial turnover are the three dependent variables used in order to capture varied aspects of SME performance. Table 1 summarises the main statistics and correlations for the dependent and independent variables used in this paper. Correlation indexes among SME performance indicators are under 0.3, which indicates that redundancies, absenteeism and financial turnover measure different aspects of SME performance and validates the inclusion in analysis of all three dependent variables.

\section{TABLE 1 NEAR HERE}

Redundancies are reported in response to the question "How many people in your organisation have been made redundant due to recession in the last 12 months?". The majority of the sampled SMEs (109 SMEs, or 82 percent) reported not laying off employees due to recession. Still, permanent employees were laid off in 24 SMEs, or one in six of the organisations in the sample, and the size of redundancies ranged from one to 14 permanent employees. A total of 87 permanent employees were, therefore, laid off due to the recession, representing 3.4 percent of the 2,509 employees in the sample. Moreover, it is important to remember that these labour turnover figures, though relatively small, usually represent a proportionally significant reduction in an SME's workforce. In fact, data indicate that due to the recession in the 12 months up to July 2009, and taking 2008 as the base year, 16 SMEs, representing 12 percent of SMEs in the sample, released more than 10 percent of their workforce.

Absenteeism is measured as work days lost per employee in the 12 months up to July 2009 . These exclude work days lost as part of authorised leave of absence, employee participation on secondment or courses, or days lost through industrial action. Descriptives show that zero-levels of absenteeism per employee are reported in 2009 for 35 percent of SMEs in the sample. The average reported annual absence is 5.5 days per employee, which is relatively lower than the British national average in the private sector standing at 6.4 days in 2009 (CIPD 2009). One of the few industry reports analysing workplace practices under recession during 2009 also highlights that four in ten employers intended to increase their organisational focus on reducing absence levels and associated costs (CIPD 2009). This is in line with predictions based on the economic shirking models, whereby increased unemployment or job security threats are expected to exert downwards pressure on absenteeism levels (Shapiro and Stigliz 1984).

Financial turnover is reported by SMEs as total turnover obtained in the 12 months up to July 2009. This data is used for the third dependent variable which is an objective measure of financial corporate performance. Due to skewness, a natural logarithmic transformation is employed. In the sample used here, annual financial turnover figures in 2009 reached on average under half a million pounds, with half of the SME respondents reporting that their financial turnover was under 210,000 British pounds (335,741 US dollars).

\section{Independent Variables: Workplace Flexibility Practices}


A total of twelve independent variables are analysed, comprising three sets of four WFPs included in analysis for each flexibility area: numerical, functional and cost. An interesting finding, in Table 1, is the large extent to which SMEs implement some WFPs. SMEs report making significant use of WFPs overall, and focusing upon certain types of WFPs before the recession. In particular, faced by recessionary pressures, SMEs experimented with extending the range of WFPs implemented. About a third of the SME sample made use of part-time working and staff pay-freezes; over 40 percent used home or mobile work and family friendly practices; and 70 percent or more offered job security, training or job enrichment, and used teams, job autonomy or employee involvement.

This result is in line with those that point to SME inherent flexibilities in adopting practices, yet, due to the sense of informality in the way SMEs adopt practices, the latter may limit the development of more complex working arrangements (Smith and Zagelmayer 2010; Tocher and Rutherford 2009). Moreover, the fact that SMEs have more limited resources to withstand market pressures arising from recessionary condition - and, thereby, have a high incentive to implement human resource innovations - may also frustrate a consistent, systematic development of WFP bundles due to the lack of HRM specialisation and/or resources made available to train managers and hence raise their awareness of the potential benefits derived from WFPs (Trocher and Rutherford 2009). Hence, there is an expectation in the literature that SMEs may implement a mix of irregular, informal practices (Smith and Zagelmayer 2010). By contrast, this paper shows a rather consistently high number of WFPs are implemented in the sample of SMEs analysed, and as a consequence, it is this degree of implementation that is an unexpected, positive finding.

The selection of twelve WFPs, shown in Table 1, is made based on a variety of criteria, including: the extant literature interest in the particular WFPs; the incidence of practices as shown in the means column in Table 1; and the correlation coefficients between / among practices. ${ }^{7}$ According to the latter criterion, where correlation coefficients were found to be above 0.7 , and where there was an intrinsic relationship among practices, WFPs were included in analysis as a representation of more than one practice. This was the case for four of the twelve WFPs: (1) Home_or_MobileWork representing home working or mobile working; (2) Teams_or_JobAut_or_EI representing teamworking, job autonomy or employee initiative; (3) Train_or_JobEnrichment representing training or job enrichment via training; and (4) MgtPayCut_or_PayFreeze_or_BonusCut representing management pay-cuts, freezes or bonus cut. The standard deviation column in Table 1 shows that the incidence of flexibility practices was wide in the SMEs sample, with values around 30 percent to 50 percent.

\section{Method and Methodology}

The following economic models are constructed to test each of the three hypotheses:

\footnotetext{
${ }^{7}$ See Appendix 1 containing a brief description of the twelve WFPs.
} 
Redundancies $=a_{1}+b_{1} F I R M+c_{1} W F P+u_{1}$

Absenteeism $=a_{2}+b_{2} F I R M+c_{2} W F P+u_{2}$

Financial Turnover $=a_{3}+b_{3} F I R M+c_{3} W F P+u_{3}$

where, the left-hand side terms are the dependent variables; for $i=1,2$, to 3 the $a_{i}$ are constant terms, $b_{i}$ and $c_{i}$ are coefficients to be estimated and $u_{i}$ are error terms; FIRM is a vector of SME workplace characteristics; and WFP is a vector of workplace flexibility practices. Since WFPs are entered in each equation as three sets of numerical, functional and, respectively cost WFPs, there are nine econometric models tested (see Figure 1).

\section{FIGURE 1 NEAR HERE}

The dependent variables Redundancies and Absenteeism have non-negative integer values and a non-negligible proportion of non-zero values pertaining to a positive finding that despite recession most SMEs report zero levels of absence per employee and manage not to make any of their permanent employees redundant. So the appropriate econometric estimation for models (1) and (2) is zero-inflated Poisson models. This is indicated by the Vuong (1989) test statistic, which at positive levels above 1.96 shows a preference of a zero-inflated Poisson model over a simple nonzero-inflated Poisson regression. ${ }^{8}$ Model (3) is estimated as a log-linear model via a multiple linear regression. Encoding financial turnover using the natural logarithm function allows this dependent variable to follow the normal distribution so linear regression can be applied. The large selection of practices used in this study has captured significantly the variance in SME performance, as shown by values of $R$ squared around 32 percent and highly significant $F$ test statistics.

Multicollinearity is not an issue in analysis, as can be seen in the correlation matrix in Table 1 where, with a few exceptions, the absolute magnitude of correlations is below 0.3. The finding that SMEs in the sample did not implement WFPs in a strong associative way, offers support to the decision of assessing the relationships between individually specified WFPs and SME performance indicators. Thus, in contrast to indirectly modelling workplace flexibility via 'bundles' of practices, this paper pursues a direct and individual analysis of relationships between WFPs and SME performance indicators. ${ }^{9}$

In addition to WFPs, a set of six workplace characteristics was introduced in each model to control for effects on company performance other than those related to WFPs. These were: firm size; a dummy for family firm ownership; a dummy for the firm being active in the manufacturing sector; the share of female employees in the non-managerial

\footnotetext{
${ }^{8}$ See Appendix 2 containing technical notes on the methods of analysis used.

${ }^{9}$ The 'bundle' hypothesis refers to testing whether practices may be grouped into scales, scores or indexes of practices, using factor analysis for such grouping. However, there is criticism that, via these techniques, practices would be grouped in an ad-hoc manner, too remote from rationales of implementation in the firm, hence certain authors have cautioned against 'bundles' (Black and Lynch 2001; Van der Meer and Ringdal 2009).
} 
workforce; the share of female managers in the managerial workforce; and a dummy for the SME manager reporting perceived high market competition.

\section{Discussion of Results}

Table 2 shows a summary of results and lists, at a glance, the statistically significant relationships between WFPs and the three SME performance indicators: redundancies, absenteeism and financial turnover. The interesting variation in the connotation of results, whereby some WFPs are positively or negatively associated with SME performance, justifies the rationale for the disaggregated approach adopted by this paper and the testing of different performance measures.

\section{TABLE 2 NEAR HERE}

There is mixed support for the three hypotheses established in this paper. Potential trade-offs faced by SMEs are highlighted, since some WFPs may have a positive relationship with a performance measure, but a negative relationship with another performance measure. For instance, staff pay freeze is likely to have a positive relationship with financial turnover, but a negative relationship with redundancies and absenteeism. On the one hand, as hypothesised, relationships between some WFPs and SME performance indicators have a positive connotation. For example, family friendly practices, training and job sharing are associated with low absenteeism, while flexitime and profit related pay are associated with low redundancies. On the other hand, some WFPs have a negative relationship with SME performance. For instance, location flexibility via working from home or mobile work, Home_or_MobileWork, is linked with high absenteeism and low financial turnover.

Full results, shown in Tables 3,4 and 5, are obtained by testing relationships between WFPs and SME performance while WFPs are introduced in three sets: numerical flexibility practices, functional flexibility practices, and cost flexibility practices. Hence, there are three economic models tested for each of the three SME performance indicators, leading to the total of nine models. ${ }^{10}$



TABLE 3 NEAR HERE

\section{TABLE 4 NEAR HERE}

\section{TABLE 5 NEAR HERE}

Within the numerical, functional and cost types of workplace flexibility, WFPs are analysed in decreasing incidence order, which enables observing that the most used practices are not necessarily also those with the most significant positive association to SME performance. For instance, in the functional flexibility area, the WFPs with the

\footnotetext{
${ }^{10}$ Due to a relatively low number of observations in the sample of 135 SMEs, and to an interest in assessing separately the three specific areas of workplace flexibility (namely, numerical, functional and cost WFPs), the twelve WFPs of interest in this paper are not entered all at the same time in a single analysis, but rather introduced as three sets of four practices at a time. See Figure 1.
} 
highest incidence is Teams_orJobAut_orEI and results show it has a negative relationship with SME performance, being linked with high levels of absenteeism.

The literature has suggested that micro-SMEs, defined as SMEs with fewer than ten employees, have ways of organising and responding to their environment which may be different than their larger SME counterparts. For instance, Way (2002) suggests that micro SMEs may be more labour-intensive and that their sources of competitive advantage would be even more limited. Therefore, results in this paper were also estimated only for the restricted sample of micro-SMEs. It can be reported that results for the micro-SMEs did not differ substantially from the overall results. $^{11}$

The remainder of the paper presents, in a joined way, the relationships between, on the one side, workplace characteristics, numerical WFPs, functional WFPs and cost WFPs, and, on the other side, the three SME performance indicators which are redundancies, absenteeism and financial turnover.

\section{Workplace Characteristics}

As shown in Tables 3, 4 and 5, most relationships tested between SME workforce size and the three SME performance indicators are significant or highly significant. Larger SMEs have a higher propensity, and indeed greater scope, to downsize under recessionary pressures and are associated with high levels of absenteeism. Indeed, Agency Theory suggests that this type of finding may be due to absence being expensive and difficult to monitor when managing larger scale organisations (Eisenhardt 1989). An alternative explanation is that larger SMEs are more likely to suffer from the free-rider problem; the larger the workplace, the easier to fail to notice the absence of an employee when other employees are present. Furthermore, absenteeism behaviour has been shown in the psychology literature to be sometimes influenced by other people's decisions and the size of their group (Olson 1965). So a reason for high absenteeism in larger SMEs is that people identify less with one another in bigger groups, making them more likely to report sick even though that would let their colleagues down. In relation to the third dependent variable, larger SMEs are more likely to associate with high levels of financial turnover, which is an intuitive result. The latter is based, theoretically, on the argument that economies of scale lead to a positive correlation between firm size and profitability (Hall and Weiss 1967), or that firms operate in strategic similar-sized groups thus allowing them more market power the bigger their firm size (Caves and Porter 1977).

Family ownership is associated with relatively low levels of redundancies but high levels of absenteeism. It may create a different structure of leadership and management which is more cohesive with regard to avoiding layoffs in recession, but less efficient at counteracting absenteeism. The related literature offers some support to this

\footnotetext{
${ }^{11}$ These results are available from the authors on request.
} 
interpretation. Firstly, regarding layoffs, low levels of redundancies may be the result of strong bonds formed within family-owned firms, creating a sense of mutual obligation among employees, and allowing better performance, communication and integration within the firm when managerial behaviour is closely monitored (Bacon and Hoque 205; Chrisman et al. 2007; Chu 2011). It may also be the case that greater emphasis on efficiency, in family-owned SMEs, could lead to fewer redundancies due to layoffs being perceived as relatively more costly, in view of the limited resources available to the firm, whilst also negating the human resource investment - such as via training undertaken by the firm in those employees made redundant (Kim and Gao 2013; Kotey and Folker 2007). Secondly, regarding absenteeism, the link between family ownership and high levels of absenteeism could reflect the finding that family-owned firms may have lower capability to set clear targets for employees, and consequently exhibit more informal employee relations (Bacon and Hoque 2005; Battisti et al. 2009). For instance, Moshavi and Koch (2005) suggest, rather counter intuitively, that family-owned firms are less likely to adopt family-friendly WFPs; the potentially consequent family-work tensions experienced by employees may explain, partially, the relatively high levels of absenteeism associated with family ownership in this paper. Similarly, Bloom and Van Reenen (2006b) and Oswald et al. (2009) link a high proportion of the poorly managed firms to family ownership, whilst Woodland et al. (2003) find that WFPs are more prevalent in the public than private sector. In view of these insights, it is possible that the current analysis, based upon a sample composed of a majority of family-owned firms in the private sector, may under-estimate the incidence and usefulness of WFPs in SMEs.

It has been suggested that workplace practices, for those SMEs in the manufacturing sector, would have a different role than in the service sector, for example since the share of employment costs in production costs is dissimilar (Bartel, 2004). This paper finds relatively little evidence for this difference, since the manufacturing sector variable is relatively not significantly associated with SME performance in Tables 3, 4 and 5.

The gender composition of the workplace has been analysed intensively in relation to the assumption that a workforce with a larger female proportion would implement particular types of flexibility practices (Visser and Williams 2006; Moshavi and Koch 2005). Indeed, a large body of literature has focused on the issues related to gender composition in the workplace, such as with regard to work-life balance, analysing sometimes issues relevant to particular segments of the female workforce e.g. managerial / professional women (Broadbridge 1998; Burke 2001; Brett and Stroh 2003; Greenhaus and Beutell 1985; White et al. 2003). Women may suffer more from family-work conflict, and organizations employing more female workers rely inherently more on women, hence WFPs profiles may be different in these organisations. Thus, in this paper, two variables assess the female composition of the workforce. Firstly, a larger female workforce composition has been generally associated with more part-time work, 
casualised contracts, and family related practices (Cassidy and Sutherland 2008; Manning and Petrongolo 2008). Under the assumptions made by the core-periphery theory, with peripheral workers most likely to be affected by recession, workplaces with more casualised contracts would expect to experience high levels of redundancies. Moreover, in the absenteeism literature, the female employee has usually been found to have higher levels of absence than male employees (Cassidy and Sutherland 2008). When compared to the literature, the findings here do not confirm the casualised contract expectations, but confirm the latter expected relationship, namely that workplaces with more female employees suffer from higher levels of absenteeism (StaffFemaleShare is highly significant in Table 4, Model 4).

Secondly, the role of the female share of managers, in relation to organisational performance, has received little attention, whereas this aspect of organisational structure may be relevant to the intrinsic profile of workplace flexibility adopted by the SME. If analysing the gender of the decision-makers, most studies tend to take into account only the gender of the senior manager (see Lokke 2007), whereas Ingram and Simons (1995) find that the proportion of female managers can be linked to the family-work responsiveness of a business. In the Lancashire SME sample, $41 \%$ of the SMEs have entirely male managerial leaders, whilst just under half of SMEs are led by both male and female managers, and $13 \%$ of SMEs are entirely led by female managers. The analysis contained in this paper appears to indicate that the share of female managers is directly linked to a high likelihood for permanent redundancies, and especially to high absenteeism. This may indicate, perhaps, that female managers might prove more sympathetic to absence than male counterparts, possibly due to their own experience in this area, or that employees copy their manager 'model' behaviour (Kristensen et al. 2006; Nielsen 2008; Perry, Kulik, and Zhou 1999; Visser and Williams 2006).

Market competition (Table 3) is highly significant in Model 2 where it has a negative association with redundancies. It may imply that the SME prefers to retain experienced employees during recession, as opposed to cutting costs via reducing permanent employees, in order to maintain productive potential for the economic recovery.

Moreover, in Table 4, all models show a highly significant and negative association between a relatively intense market competition and absenteeism, suggesting that more competitive settings allow for lesser scope for absence, whether justified or 'shirking'. The highly significant and negative association between greater market competition and absenteeism, may imply that employees in SMEs respond via low absenteeism (possibly through reduced shirking rates) to the pressures that a highly competitive market places upon the organisation. If so, this would appear to be a clear example of market discipline.

\section{Numerical WFPs}


Home or mobile working is associated with high absenteeism (Table 4) and low financial turnover (Table 5), which would appear to confirm the negative perceptions, held by many managers, that these initiatives can facilitate shirking. It does, moreover, conflict with the literature in this aspect, which generally supports overall positive connotations for implementing home-working, a flexibility practice highly-desired by employees (Gray 2002). Indeed, it is often portrayed as providing an alternative to absenteeism, especially incidences of parent absence due to child illness. This finding, however, is in line with previous studies which found either little association between working from home and corporate performance (Whyman et al. 2009), or suggested that absenteeism may indeed increase if home working resulted in the boundary between home and work being more disputed, the employee working too many long days, and work-life conflict ensued (Russell, O'Connell, and McGinnity 2009). This is an important matter to clarify, since research on modern employment relationships mentions increasing numbers of individuals working mainly from home or via mobile work in the UK (Felstead et al. 2002; Gariety and Shaffer 2007). Thus, it remains uncertain the extent to which home-working could be a mutually agreed flexible solution to keeping workforce on payroll during low labour activity.

Family friendly practices are highly significantly linked to low absenteeism levels, with marginal effects showing a predicted three day per employee per year decrease in absenteeism if family practices are implemented (Table 4, Model 4). This positive finding is in line with results in the literature indicating that employees supported in their workplace are more likely to reciprocate by taking less absence and being loyal to their employers (Giardini and Kabst 2008; Goff, Mount, and Jamison 1990; Meyer and Allen 1997). Moreover, organisations with family-friendly policies are found to be better at retaining employees; this is the case even when the respective employees choosing to remain within the organisation do not use these policies themselves, suggesting that the use of family friendly practices, albeit by colleagues of an employee, has an indirect positive spill-over effect on employee retention (Grover and Crooker 1995; Yanadori and Kato 2009).

Part-time working is associated with high redundancies (in Table 3) and low financial turnover (Table 5), but with low absenteeism (Table 4). The association with redundancies may be due to part-time working being taken up by employees who would otherwise want to be employed full-time but who cannot find such jobs in recession. This association may also be a reaction to SMEs facing financial stress, due to falls in demand, cost pressures or need to intensify work and efficiency, whereby employers reduce formerly full-time positions and replace them with part-time contracts. Moreover, it may conceivably reflect a link with low financial turnover if employers under-utilise part-time workers by trapping them in a circle of fewer training and growth opportunities (Francesconi and Gosling 2005; Stevens, Brown, and Lee 2004). 
The use of part-time workers is significantly linked with low rates of absence. The result is significant in both the main and the marginal effect (Table 4, Model 4), showing a 1.3 day of annual absence per person predicted difference between SMEs with part-time workers and those without. This is a result in line with the literature, such as Barmby, Orne, and Treble (1995) reporting that full-time workers had significantly higher absence rates than part-time workers, or Giardini and Kabst (2008) finding that a bundle of flexibility practices including part-time work reduced absenteeism. One possible theoretical explanation is that, as flexible working time options become available, workers can optimise their labour-leisure options to match their contracted with their desired hours, hence absence may decrease. Alternatively, it might reflect a less secure employment position resulting in decreased shirking due to the pressurised nature of part-time contracts (Visser and Williams 2006). Either way, these results have been replicated by an extensive study of absenteeism at European level (Lusinyan and Bonato 2007).

Flexitime is highly significantly associated with low redundancies (Table 3), hence this WFPs is one which SMEs may be able to implement in order to avoid recession-imposed downsizing. So, by varying the times when staff start or end working, the firm may be able to fit the cost cutting scenarios imposed by recession without needing to lay off as many permanent employees as otherwise.

\section{Functional WFPs}

Most of the functional flexibility practices are highly significantly associated with lower absenteeism levels, with results of a magnitude that implies SMEs adopting Training_Job_Enrichment, Job_Security or Job_Sharing may have up to six days less absence per employee per year (Table 4). This is a significant finding, suggesting that these WFPs may have the potential to dramatically reduce absence, which is reported to average in Britain at around seven days per employee per year (CIPD 2009).

The exception is Teamwork or job autonomy or employee involvement which is highly significantly associated with high levels of absenteeism (in Table 4), in the order of a predicted extra 3.8 days per employee per year. Forms of interdependent worker productivity, such as teamwork, are expected to face a higher cost of absence due to incurring collectively increased costs from lost productivity, so are found to usually spend more money to lower their absence rates (Heywood, Jirjahn, and Wei 2008). However, SMEs have a more limited resource base to monitor absence. Still, the result is counterintuitive, because better working conditions, such as where employees have discretion over their tasks and feel involved in their work, would be expected to lead to lower absence.

There are two feasible explanations for this finding. The first notes similar surprising findings that in some organisations flexible job design or teams do not have any impact on absence, as indicated by a Canadian study using nationally representative data from 1999-2002 (Dionne and Dostie 2007). Moreover, Drago and Wooden (1992) 
suggest that the relationship between workgroup cohesion and absenteeism may be mediated by job satisfaction, and if job satisfaction is low, there result is higher absence. Peer pressure may produce a similar result, possibly arising from an increase in monitoring or stress during recession, leading to unpleasant working conditions (Batt and Appelbaum 1995). Teamworking has indeed been found to inculcate a culture of tense supervision (Batt 2004). The finding that this WFP is the most widespread in the sample, at 83 percent, is interesting, portraying SMEs in a similar respect to the most innovative high-performance organisations which embrace advancements in employment relations regarding employee discretion and participative working arrangements. However, the second possible explanation for the finding may be the breadth of definition certain SME managers may ascribe to the term teamworking, whereby almost any activity might potentially be included, and hence the variable is failing to capture what it intended. Further fieldwork would be required to determine the true cause.

Training or job enrichment is correlated with higher proportion of employees with degree, a variable which could not be used in the analysis because it was also (negatively) highly correlated with family-owned SMEs. However, the correlation with relatively highly-educated workforce may help explain the association with absenteeism (Jones et al. 2009). Results in Table 4 show that absenteeism may be reduced by 5.9 days per employee per year in SMEs utilising this WFP. In contrast to the view that WFPs may have limited incidence in SMEs, training or job enrichment is the second most spread WFP in the sample, being utilised by fully 71 percent of SMEs included in the sample, followed closely in the third place at 70 percent by job security.

Job security is associated with high redundancies (in Table 3), but low absenteeism (Table 4) and high financial turnover (Table 5). The latter observation is unproblematic, with employees who feel safe in their job potentially experiencing greater motivation, whilst tenure is associated with greater human capital acquisition and hence productivity, and therein associated with higher corporate performance measures. In more detail, compared to SMEs without job security for employees, results in Table 5 suggest that SMEs offering employees job security are likely to have financial turnover levels that are higher by a factor of $1.2{ }^{12}$ Interestingly, the relationship between job security and absenteeism suggests that motivation effects outweigh the potential to shirk, at least amidst recessionary conditions. However, it is the link between job security and high redundancies which is most intriguing. This may reflect one of a number of potential causes, including changing definitions of what constitutes 'security', particularly amidst a recession. Similarly, it may reflect a disparity between what employers claim is a 'secure' working environment and the evidence drawn from objective data. Alternatively, SMEs with job security, which is usually

\footnotetext{
${ }^{12}$ In models where the dependent variable has been log-transformed and the predictors have not, the format for interpretation is that dependent variable changes by $100 *$ (coefficient) percent for a one unit increase in the independent variable while all other variable in the model are held constant. Hence, if a certain practice is introduced (that is a change from zero to one in its status equivalent to a one unit increase in the independent variable), the dependent variable which is natural logarithm of turnover changes, as a percentage, by 100 times the coefficient.
} 
associated with high-end jobs, may be a priori suffering more from recession, suggesting that sectors of highly-skilled workforce could have been relatively harder hit by recession-related redundancies than those with lower skilled workforce.

Job sharing is significantly linked with low redundancies (Table 3) and highly significantly linked with low absenteeism (Table 4). As shown in Table 1, Job sharing is the WFP with the lowest incidence in the sample (12 percent). Hence, the finding that it may associate with low redundancies points to the unexploited potential of this practice to help SMEs maintain their workforce size, whilst also benefiting from low absenteeism. Yet, the low uptake of this practice may hide certain drawbacks feared by the employees who would be job sharing. Reporting on Australian data, McDonald, Bradley, and Brown (2008) mention that this WFP can be mixed with part-time work, but very little research has looked at the distinction and its consequences to career opportunities. Still, both WFPs may lead to similarly reduced career opportunities, due to the perception that job-sharing, like part-time working, is the choice of individuals avoiding the toil of full-time work (McDonald, Bradley, and Brown 2008).

\section{Cost WFPs}

Managerial pay cut or pay freeze or bonus cut shows a significant association with low financial performance (Table 5). Managerial remuneration has attracted a lot of attention recently in Britain, with widely publicised incidences of top executives seeing their pay size disputed and having to forgo bonuses (see, for example, Hutton 2010). This result seems intuitive since firms with high levels of performance would not be expected to need to cut managerial pay, whereas firms experiencing financial pressures would be interested to adjust costs including the implementation of management pay cuts.

Staff pay freeze is highly significantly linked to high redundancies (Table 3) and significantly linked to high absenteeism (in Table 4). An interpretation of these findings may suggest that staff pay-freezes were implemented in SMEs already suffering from the economic recession, hence where staff was being laid off, whilst neo-classical economics might suggest that a natural response to lower real rewards would be to reduce work effort. Results also show that this cost reduction method associates with high financial turnover, but at marginal significance.

A surprising finding is the lack of significance of one of the most frequently discussed high-performance practice, namely individual performance related pay. This may arise due to a faulty method of implementation, whereby the links between performance and reward are obfuscated, or where rewards are skewed to certain groups within the workforce, or simply due to rates being set too low, and thereby failing to incentivise staff to achieve desired goals. Authors have indeed pointed to the importance in British workplaces of analysing in-depth the way in which performance related pay is implemented by managers as a complex instrument to negotiate employee productivity 
(Marsden 2004). In a detailed study of performance-related-pay in the British public sector in the 1990s, Marsden (2004, p. 351) concludes that special attention needs to be paid to how performance norms are set by managers and how performance is appraised since otherwise the scheme may not motivate employees but instead lead to divisiveness and lack of an association with higher productivity.

Profit related pay is significantly associated with low redundancies (Table 3) and high financial turnover (in Table 5). The result echoes suggestions in the literature on forms of pay sharing that such pay systems motivate cooperation, thereby encouraging higher productivity and employee involvement (Sels et al. 2006; Shepard 1994).

\section{Conclusions}

This paper analyses the relationship between a set if twelve workplace flexibility practices (WFPs) and three SME performance indicators, namely redundancies, absenteeism and financial turnover. The paper seeks to extend the literature relating to SME workplace flexibility and objectively measured firm performance, within the context of conditions of economic recession. It includes a set of not one, but three measures of performance, thereby showcasing variations in the way WFPs associate with firm performance. Moreover, it signals the importance of disaggregation studies of workplace flexibility, thereby identifying relationships between individual WFPs and the selected performance measures. Disaggregation is significant, because it highlights that some WFPs can be 'double-edged swords', being positively associated with some performance measures, but also negatively associated with other indicators. Consequently, the range of potential trade-offs between individual WFPs, and the precise composition of a basket of human resource innovations, are emphasised as key potential factors influencing the outcomes generated by flexibility programmes.

Primary data analyses of 135 SMEs based in Lancashire, a north-west region of the UK, collected in 2009 at the height of the recent economic recession, portrays rich and varied employment relationships within respondent SMEs. Managers are shown to have been innovative and entrepreneurial in their reactions to recession, adapting their use of WFPs quickly, despite the popular view that SMEs would be limited in the scope of implementing WFPs. For instance, more than 70 percent of SMEs in the sample use training or job enrichment, offer teamwork or job autonomy, and have job security. Nevertheless, the WFPs with the highest incidence are not necessarily those which are also most likely to be associated with intended corporate performance outcomes.

Via zero-inflated Poisson and linear regressions, findings indicate which numerical, functional and cost WFPs implemented by SMEs may lead to the desired positive relationships with the three performance indicators analysed. 
The results of several econometric analyses are presented in a practitioner-friendly style, especially in the summary compiled in Table 2, but also throughout the paper.

Findings are relevant to practitioners and policy makers hoping to assist SMEs to enhance performance, showcasing the importance of using a combination of measures to assess the various relationships between WFPs and SME corporate performance. For instance, if intending to choose a specific basket of WFPs to implement, depending upon individual circumstances and what the firm wants to achieve, Table 2 can inform SME managers which WFPs could be most helpful. Indeed, as shown in Table 2, a different set of WFPs could be selected if an SME wanted to target redundancies (helpful WFPs here could be flexitime, profit related pay, and job sharing), absenteeism (useful WFPs here could be training or job enrichment, job security, job sharing, family friendly practices, and part-time work), or financial turnover (target WFPs here could be profit related pay, job security and staff pay freeze).

The results indicate that the size and gender composition of an organisation appear to be significant factors, alongside WFPs such as flexitime, job sharing and job security, training and remuneration scheme changes. Firstly, with regard to numerical flexibility, flexitime links to low absenteeism, and family friendly practices link to low redundancies, but some numerical WFPs also associate with low financial turnover or are not significantly related to financial turnover. Secondly, with regard to functional flexibility, all WFPs in this paper appear to have a considerable potential in relation to absenteeism, with training or job enrichment, and job security being linked to lower levels of annual absenteeism of up to six days per employee. Lastly, with regard to cost flexibility, WFPs such as freezing staff pay and management pay, or cutting management pay and bonuses are practices which are found to be of limited help to SMEs dealing with recessionary pressures. Staff pay-freezes link to a high number of permanent-employee redundancies, whilst cost flexibility practices such as staff pay-freezes and management pay-cuts or management payfreezes link to low financial turnover.

Limitations of this study arise mainly from the nature and size of the data. Firstly, one limitation derives from its cross-sectional nature, and hence inability to assign causality between observed variable relationships. Additional data sampling, introducing longitudinal aspects to the study, would, therefore, enhance the analysis. Secondly, there is relative over-selection of larger SMEs in the sample, yet the sample is matched relatively well to the regional or national profile of SMEs. Thirdly, the data sample size yields sufficient small and medium firm responses for data analysis in an otherwise relatively small sample. A larger dataset, consisting of more respondents and more answers per respondent, would allow for a wider variety of relationships between WFPs and firm performance to be tested at the same time as well as a more complex investigation of associations. Relatedly, the econometric models constructed had to be parsimonious relative to the number of variables tested, due to a combination of small number of SME 
respondents and incomplete questionnaire responses. A larger dataset would also allow for splitting the sample according to various defining workplace characteristics, such as conducting comparative analysis on the workplace flexibility practices implemented in SMEs with a preponderance of female employee managers. Nevertheless, the paper highlights the degree of innovative response to conditions of constrained market demand, whilst simultaneously identifying potential benefits which SMEs may derive from further WFPs implementation.

This paper addresses gaps in research on the use and incidence of WFPs in SMEs during a recessionary climate.

Results validate the rationale for this research and offer reasons to encourage more similar research on workplace flexibility. There are good reasons to conclude that more lessons need to be learned in terms of managing workplace flexibility in SMEs during recession.

\section{References}

\section{References}

Atkinson, J. (1984). Flexibility, Uncertainty and Manpower Management. Report 89. Institute of Manpower Studies.

Appelbaum, E., T. Bailey, P. Berg, and A. L. Kalleberg (2000). Manufacturing Advantage: Why High-Performance Work Systems Pay Off. Cornell University Press, Ithaca NY.

Bacon, N., and K. Hoque, (2005). "HRM in the SME Sector: Valuable Employees and Coercive Networks," International Journal of Human Resource Management 16 (11), 1976 - 1999.

Barmby, T. A., C. D. Orme, and J. G. Treble (1995). "Worker Absence Histories," Labour Economics 2 (1), 53-66.

Barmby, T. A., M. G. Ercolani, and J. G. Treble (2004). "Sickness Absence in the UK: 1984-2002," Swedish Economic Policy Review 11 (1), 65-88.

Bartel, A. P. (2004). "Human Resource Management and Organizational Performance: Evidence from Retail Banking," Industrial and Labor Relations Review 57 (2), 181-203.

Batt, R. (2004). "Who Benefits from Teams? Comparing Workers, Supervisors, and Managers," Industrial Relations 43 (1), 183 - 212.

Batt, R., and E. Appelbaum (1995). "Worker Participation in Diverse Settings: Does the Form Affect the Outcome, and If So Who Benefits?," British Journal of Industrial Relations 33 (3), 353-378.

Batt, R. and M. Valcour (2003). "Human Resources Practices as Predictors of Work-Family Outcomes and Employee Turnover," Industrial Relations 42 (2), 189 - 220.

Battisti, G., H. Celia, C. W. Clegg, X. Fu, A. Iona, and A. I. Petrescu (2009). "Capabilities versus Productivity: Identifying the Weaknesses in the UK Retail Industry," Advanced Institute of Management (AIM) Executive Briefings: London.

Becker, G. (1964). Human Capital: A Theoretical Analysis with Special Reference to Education. New York: Columbia University Press.

Berg, P., E. Appelbaum, T. Baily, and A. L. Kalleberg (2004). "Contesting Time: International Comparisons of Employee Control of Working Time," Industrial and Labor Relations Review, 57 (3), 331 - 349.

BERR [UK Department for Business, Enterprise and Regulatory Reform] (2008). SME Statistics for the UK and Regions 2007. http://stats.berr.gov.uk/ed/sme/smestats2007.xls Accessed 09 September 2009.

Black, S. E., and L. M. Lynch (2001). "How to Compete: The Impact of Workplace Practices and Information Technology on Productivity," Review of Economics and Statistics 83 (3), 434 - 446.

Bloom, N., and J. Van Reenen (2006a). "Management Practices, Work-Life Balance and Productivity: A Review of Some Recent Evidence," Oxford Review of Economic Policy 22 (4), 457 - 482.

Bloom, N., and J. Van Reenen (2006b). "Measuring and Explaining Management Practices Across Firms and Countries," Centre for Economic Performance, Discussion Paper 716.

Brett, J. M., and L. K. Stroh (2003). "Working 61 Hours a Week: Why Do Managers Do It?, " Journal of Applied Psychology 88 (1), 67 88 .

Broadbridge, A. (1999). "Retail Managers: Stress and the Work-Family Relationship, " International Journal of Retail and Distribution Management 27 (9), $374-382$.

Brown, S., and J. G. Sessions (1996). "The Economics of Absence: Theory and Evidence," Journal of Economic Surveys 10 (1), 23 - 53.

Bryson, J. R. (1996). "Small Business Service Firms and the 1990s Recession in the United Kingdom: Implications for Local Economic Development," Local Economy 11 (3), 221 - 236.

Bryson, A., F. Green, and K. Whitfield (2008). "A Quarter Century of Workplace Employment Relations Surveys," British Journal of Industrial Relations 46 (4), 577 - 586.

Buller, P. F., and G. M. McEvoy (2012). "Strategy, Human Resource Management and Performance: Sharpening Line of Sight," Human Resource Management Review 22 (1), 43 - 56.

Burke, R. (2001). "Organizational Values, Work Experiences and Satisfactions among Managerial and Professional Women, " The Journal of Management Development 20 (4), 346 - 354.

Cameron, A. C., and P. K. Trivedi (1998). Regression Analysis of Count Data. Cambridge, UK: Cambridge University Press.

Carlson, D. S., N. Upton, and S. Seaman (2006). "The Impact of Human Resource Practices and Compensation Design on Performance: An Analysis of Family-Owned SMEs," Journal of Small Business Management 44 (4): $531-543$. 
Carmeli, A., and J. Schaubroeck (2008). "Organisational Crisis - Preparedness: The Importance of Learning from Failures," Long Range Planning 41 (2), 177 - 196.

Caroli, E., J. Gautie, C. Lloyd, A. Lamanthe, and S. James (2010). "Delivering Flexibility: Contrasting Patterns in the French and the UK Food Processing Industry," British Journal of Industrial Relations 48 (2), 284 - 309.

Cassell, C., S. Nadi, M. Gray, and C. Clegg (2002). "Exploring Human Resource Management Practices in Small and Medium Sized Enterprises," Personnel Review 31 (6), 671 - 692.

Cassidy, D., and J. Sutherland (2008). "Going 'Absent', Then Just 'Going'? A Case Study Examination of Absence and Quitting," Economic Issues 13 (2), 1 - 19.

Caves, R. E., and M. E. Porter (1977). "From Entry Barriers to Mobility Barriers: Conjectural Decisions and Contrived Deterrence to New Competition", Quarterly Journal of Economics 91 (2), 421 - 441.

CBI [Confederation of British Industry] (2009). Employment Trends 2009: Work Patterns in the recession. Report. June.

CBI [Confederation of British Industry] (2010). Marking Britain the Place to Work: An Employment Agenda for the New Government. Report. June.

Central Lancashire Business Directory 2008 - 09 [CLBD 2008-09] (2009). CD-ROM. Lancashire City Council. Preston. U.K. http://www.preston.gov.uk/business/business-directory/ . Accessed 02 May 2009.

Chandler, G. N., and G. M. McEvoy (2000). "Human Resource Management, TQM, and Firm Performance in Small and Medium-Size Enterprises," Entrepreneurship: Theory and Practice, 25 (1), 43 - 58.

Chrisman, J. J., J. H. Chua, F. W. Kellermanns, and E. P.C. Chang (2007). "Are Family Managers Agents or Stewards? An Exploratorkandely Study in Privately Held Family Firms," Journal of Business Research 60 (10), 1030-1038.

Chu, W. (2011). "Family Ownership and Firm Performance: Influence of Family Management, Family Control, and Firm Size," Asia Pacific Journal of Management 28 (4), 833-851.

CIPD [Chartered Institute of Personnel and Development] (2009). Absence Management Annual Survey Report. Report, July.

Deshpande, S. P., and D. Y. Golhar (1994). "HRM Practices in Large and Small Manufacturing Firms: A Comparative Study," Journal of Small Business Management 32(2), 49-59.

Dex, S., and F. Scheibl (2001). "Flexible and Family-Friendly Working Arrangements in UK-Based SMEs: Business Cases," British Journal of Industrial Relations 39 (3), 411 - 431.

Dex, S., and C. Smith (2002). The Nature and Pattern of Family-Friendly Employment Policies in Britain. Joseph Rowntree Foundation and Policy Press, Bristol.

Dillman, D. (1999). Mail and Internet Surveys: The Tailored Design Method. New York: Wiley.

Dionne, G., and B. Dostie (2007). "New Evidence on the Determinants of Absenteeism Using Linked Employer-Employee Data," Industrial and Labor Relations Review 61 (1), 108 - 120.

Doeringer, P and M. Piore (1971). Internal Labor Markets. D.C. Heath, Lexington, Mass.

Drago, R., and M. Wooden (1992). "The Determinants of Labor Absence: Economic Factors and Workgroup Norms across Countries," Industrial and Labor Relations Review 45 (4), $764-778$.

DTI [Department of Trade and Industry] (2003). Balancing Work and Family Life: Enhancing Choice and Support for Parents. HM Treasury, January.

DTI [Department of Trade and Industry] (2005). Workplace Industrial Relations Survey (WIRS). 2nd Ed. Colchester: The Data Archive [distributor].

Easterby-Smith, M., R. Thorpe, and A. Lowe (1993). Management Research: An Introduction. London: Sage.

Eaton, S. C. (2003). "If You Can Use Them: Flexibility Policies, Organizational Commitment, and Perceived Performance," Industrial Relations 42 (2), 145 - 167.

Eisenhardt, K. M. (1989). "Agency Theory: An Assessment and Review," Academy of Management Review 14 (1), 57 - 74.

European Commission [EC] (2002). SMEs in Focus: Main Results from the 2002 Observatory of Europeans SMEs. Luxembourg: European Commission.

European Union [EU] (2003). "Commission Recommendation of the 6th of May 2003 Concerning the Definition of Micro, Small and Medium-Sized Enterprises," Official Journal of the European Union L 124, 36 -41, May 20th.

Evans, C., G. Harvey, and P. Turnbull (2012). "When Partnerships Don't 'Match-Up': An Evaluation of Labour-Management Partnerships in the Automotive Components and Civil Aviation Industries," Human Resource Management Journal 22 (1), 60-75.

Felstead, A., N. Jewson, A. Phizacklea, and S. Walters (2002). "Opportunities to Work at Home in the Context of Work-Life Balance," Human Resource Management Journal 12 (1), 54 - 76.

Forth, J., H. Bewley, and A. Bryson (2006). Small and medium-sized enterprises: Findings from the 2004 Workplace Employment Relations Survey. ESRC/ACAS/PSI.

Francesconi, M., and A. Gosling (2005). Career Paths of Part-Time Workers, Equal Opportunities Commission, University of Essex, UK.

Frick, B., and M. A. Malo (2008). "Labour Market Institutions and Individual Absenteeism in the European Union: The Relative Importance of Sickness Benefit Systems and Employment Protection Legislation," Industrial Relations 47 (4), 505 - 529.

Gariety, B. S., and S. Shaffer (2007). "Wage Differentials Associated with Working at Home," Monthly Labor Review, March.

Georgiadis, A., and C. N. Pitelis (2012). "Human Resources and SME Performance in Services: Empirical Evidence from the UK," The International Journal of Human Resource Management 23 (4), 808 - 825.

Giardini, A., and R. Kabst (2008). "Effects of Work-Family Human Resource Practices: A Longitudinal Perspective," International Journal of Human Resource Management 19 (11), 2079 - 2094.

Glover, L., and Butler, P. (2012). "High-Performance Work Systems, Partnership and Working Lives," Human Resource Management Journal 22 (2), 199 - 215

Goff, S. J., M. K. Mount, and R. L. Jamison (1990). "Employer Supported Child Care, Work/Family Conflict, and Absenteeism: A Field Study," Personnel Psychology 43 (4), 793 - 809.

Golden, L. (2009). "Flexible Daily Work Schedules in U.S. Jobs: Formal Introductions Needed?," Industrial Relations 48 (1), 27 - 54

Gray, H. (2002). "Family-Friendly Working: What a Performance! An Analysis of the Relationship between the Availability of FamilyFriendly Policies and Establishment Performance," May, Discussion Paper 0529, Centre for Economic Performance, London, UK.

Greene, W. H. (1994). "Accounting for Excess Zeros and Sample Selection in Poisson and Negative Binomial Regression Models," Working Paper, Stern School of Business, NYU EC-94-10.

Greenhaus, J. H., and N. J. Beutell (1985). "Sources of Conflict between Work and Family Roles.," Academy of Management Review 10 (1), $76-88$ 
Grover, S. L., and K. J. Crooker (1995). "Who Appreciates Family-Responsive Human Resource Policies: The Impact of Family-Friendly Policies on the Organizational Attachment of Parents and Non-Parents," Personnel Psychology 48 (2), 271 - 288.

Guest, D. (2011). "Human Resource Management and Performance: Still Searching for Some Answers," Human Resource Management Journal 21 (1), 3 - 13.

Hall, M., and L. Weiss (1967). "Firm Size and Profitability," Review of Economics and Statistics 49 (3), 319 - 331.

Heywood, J. S., W. Jirjahn, and X. Wei (2008). "Teamwork, Monitoring and Absence," Journal of Economic Behavior and Organization $68(3-4), 676-690$

Hill, E J., J. G. Grzywacz, S. Allen, V. L. Blanchard, C. Matz-Costac, S. Shulkin, and M. Pitt-Catsouphes (2008). "Defining and Conceptualizing Workplace Flexibility," Community, Work and Family 11 (2), 149 - 163.

Hutton, W. (2010). Hutton Review of Fair Pay in the Public Sector: Interim Report. HM Treasury. December. UK.

Ingram, P., and T. Simons (1995). "Institutional and Resource Dependence Determinants of Responsiveness to Work-Family Issues," Academy of Management Journal 38 (5), 1466 - 1482.

Jones, M. K, R. J. Jones, P. L. Latreille, and P. J. Sloane (2009). "Training, Job Satisfaction and Workplace Performance in Britain: Evidence from WERS 2004," Labour 23 (Special Issue), 139 - 175.

Kacmar, K. M., M. C. Andrews, D. L. Van Rooy, R. C. Steilberg, and S. Cerrone (2006). "Sure Everyone Can Be Replaced. But at What Cost? Turnover as a Predictor of Unit-Level Performance," Academy of Management Journal 49 (1), 133 - 144.

Kalleberg, A. L. (2001). "Organizing Flexibility: The Flexible Firm in a New Century," British Journal of Industrial Relations 39 (4), 479 $-504$.

Kelly, J. (2004). "Social Partnership Agreements in Britain: Labor Cooperation and Compliance," Industrial Relations 43 (1) 267 - 292

Kim, Y., and F. Y. Gao (2013). "Does Family Involvement Increase Business Performance? Family-Longevity Goals' Moderating Role in Chinese Family Firms," Journal of Business Research 66 (2), 265 - 274.

Kotey, B., and C. Folker (2007). "Employee Training in SMEs: Effect of Size and Firm Type Family and Nonfamily," Journal of Small Business Management 45 (2), 214-238.

Kristensen, K., H. J. Juhl, J. K. Eskildsen, N. Frederiksen, and C. Møller-Bisgaard (2006). "Determinants of Absenteeism in a Large Danish Bank," International Journal of Human Resource Management 17 (9), 1645-1658.

Lazear, E. P. (1998). Personnel Economics for Managers, Wiley, New York, NY.

Levy, M., and P. Powell (1998). "SME Flexibility and the Role of Information Systems," Small Business Economics 11 (2), 183 - 196.

Lokke, A. K., and J. K. Eskildsen (2007). "Absenteeism in the Nordic Countries," Employee Relations 29 (1), 16 - 29.

Long, J. S. (1997). Regression Models for Categorical and Limited Dependent Variables. Thousand Oaks, CA: Sage Publications.

Lusinyan, L., and L. Bonato (2007). "Work Absence in Europe," IMF Staff Papers 54 (3), 475 - 538.

Manning, A., and B. Petrongolo (2008). "The Part-Time Pay Penalty for Women in Britain," Economic Journal 118 (526), F28 - F51.

Marsden, D. (2004). "The Role of Performance-Related Pay in Renegotiating the 'Effort Bargain': The Case of the British Public Service," Industrial and Labor Relations Review 57 (3), 350 - 370.

Martinez-Sanchez, A., M. J. Vela-Jimenez, M. Perez-Perez, and P. de-Luis-Carnicer (2007). "Workplace Flexibility and Innovation. The Moderator Effect of Inter-Organizational Cooperation," Personnel Review 37 (6), 647 - 665.

Matlay, H. (2002). "Industrial Relations in the SME Sector of the British Economy; An Empirical Perspective," Journal of Small Business and Enterprise Development 9 (3), 307 - 318.

Maxwell, G., L. Rankine, S. Bell, and A. MacVicar (2007). "The Incidence and Impact of Flexible Working Arrangements in Smaller Businesses," Employee Relations 29 (2), 138 - 161.

McDonald, P., L. Bradley, and K. Brown (2008). "Visibility in the Workplace: Still an Essential Ingredient for Career Success?," International Journal of Human Resource Management 19 (12), 2198 - 2215.

Meyer, J., and N. Allen (1997). Commitment in the Workplace: Theory, Research, and Applications. Thousand Oaks, CA: Sage Publications.

Moshavi, D., and M. J. Koch (2005). "The Adoption of Family-Friendly Practices in Family-Owned Firms," Community, Work and Family, 8 (3), 237 - 249.

Nielsen A. L. (2008). "Determinants of Absenteeism in Public Organizations: A Unit-Level Analysis of Work Absence in A Large Danish Municipality," International Journal of Human Resource Management 19 (7), 1330 - 1348

Olson, M. (1965). The Logic of Collective Action. Harvard University Press, Cambridge, MA.

$\begin{array}{lllllll}\text { ONS [Office } & \text { of } & \text { National } & \text { Statistics] } & \text { (2009). } & \text { UK } & \text { Business }\end{array}$ http://www.statistics.gov.uk/downloads/theme_commerce/PA1003_2009/UK_Business_2009.pdf Accessed 04 July 2009.

Origo, F., and L. Pagani (2008). "Workplace Flexibility and Job Satisfaction: Some Evidence from Europe," International Journal of Manpower 29 (6), 539-566.

Oswald, S. L., L. A. Muse, and M. W. Rutherford (2009). "The Influence of Large Stake Family Control on Performance: Is It Agency or Entrenchment?," Journal of Small Business Management 47 (1), 116 - 135.

Osterman, P. (2000). "Work Organisation in an Era of Restructuring: Trends in Diffusion and Effects on Employee Welfare," Industrial and Labor Relations Review 53 (2), 179 - 196.

Petrescu, A. I. (2008). The Impact of Workplace Practices on Company and Employee Performance in Britain. PhD Thesis. Lancaster University Management School. UK.

Perry, E. L., C. T. Kulik, and J. Zhou (1999). "A Closer Look at the Effects of Subordinate-Supervisor Age Differences," Journal of Organizational Behavior 20 (3), 341 - 357.

Perry-Smith, J. E., and T. C. Blum (2000). "Work-Family Human Resource Bundles and Perceived Organisational Performance," Academy of Management Journal 43 (6), 1107 - 1117.

Robinson, A. M., and N. Wilson (2006). "Employee Financial Participation and Productivity: An Empirical Reappraisal," British Journal of Industrial Relations 44 (1), 31 - 50.

Russell, H., P. J. O'Connell, and F. McGinnity (2009). "The Impact of Flexible Working Arrangements on Work-Life Conflict and Work Pressure in Ireland," Gender, Work and Organisation 16 (1), 73 - 97.

Sels, L., S. De Winne, J. Maes, J. Delmotte, D. Faems, and A. Forrier (2006). "Unravelling the HRM-Performance Link: Value-Creating and Cost-Increasing Effects of Small Business HRM," Journal of Management Studies 43 (2), 319 - 342.

Shapiro, C., and J. Stiglitz (1984). "Equilibrium Unemployment as a Worker Discipline Device," American Economic Review 74 (3), 433 444. 
Shepard III, E. (1994). "Profit Sharing and Productivity: Further Evidence from the Chemicals Industry," Industrial Relations 33 (4), 452 477.

SIC [Standard Industrial Classification of Economic Activities UK]. (2003). http://www.statistics.gov.uk Accessed 07 August 2009.

Smith, M. and S. Zagelmayer (2010). "Working Time Management and SME Performance in Europe," International Journal of Manpower $31(4), 392-409$.

Spillan, J., and M. Hough (2003). "Crisis Planning in Small Businesses: Importance, Impetus and Indifference," European Management Journal 21 (3), 398 - 407.

Stavrou, E. T., C. Brewster, and C. Charalambous (2010). "Human Resource Management and Firm Performance in Europe Through the Lens of Business Systems: Best Fit, Best Practice or Both?," International Journal of Human Resource Management 21 (7), 933 - 962.

Stevens, J., J. Brown, and C. Lee (2004). "The Second Work-Life Balance Study: Results from the Employees' Survey. Employment Relations Research Series No. 27," Department for Trade and Industry, March. UK.

Storey, D. J. (2002). "Education, Training and Development Policies and Practices in Medium-Sized Companies in the UK: Do They Really Influence Firm Performance?," Omega 30, 249-264.

Tocher, N., and M. W. Rutherford (2009). "Perceived Acute Human Resource Management Problems in Small and Medium Firms: An Empirical Examination," Entrepreneurship: Theory and Practice 33 (2), 455 - 479.

Thompson, P. (2011). "The Trouble with HRM," Human Resource Management Journal 21 (4), 355 - 367.

Upchurch, M., A. Danford, S. Tailby, and M. Richardson (2008). The Realities of Partnership at Work. Basingstoke: Palgrave Macmillan.

Van der Meer, P. H., and K. Ringdal (2009). "Flexibility Practices, Wages and Productivity: Evidence from Norway," Personnel Review $38(5), 526-543$

Visser, F., and L. Williams (2006). "Work-Life Balance: Rhetoric versus Reality? An Independent Report Commissioned by UNISON," The Work Foundation, UNISON. UK.

Vuong, Q. H. (1989). "Likelihood Ratio Tests for Model Selection and Non-Nested Hypotheses," Econometrica 57 (2), $307-333$.

Way, S. (2002). "High Performance Work Systems and Intermediate Indicators of Firm Performance within the US Small Business Sector," Journal of Management 28 (6), 765-85.

White, M., S. Hill, P. McGovern, C. Mills, and D. Smeaton (2003). "High Performance Management Practices, Working Hours and WorkLife Balance," British Journal of Industrial Relations 41 (2), 175 - 195.

Whyman, P. B., and A. I. Petrescu (2013). "Partnership, Flexible Workplace Practices and the Realisation of Mutual Gains: Evidence from the British WERS 2004 Dataset," The International Journal of Human Resource Management. Special Issue: Partnership, Collaboration and Mutual Gains.

Whyman, P. B., and M. Baimbridge (2006). "Labour Market Flexibility and Foreign Direct Investment," Employment Relations, Occasional Paper, URN 06 / 1797, Department of Trade and Industry. London.

Whyman, P. B., M. Baimbridge, B. Buraimo, and A. I. Petrescu (2009). "Workplace Flexibility and Corporate Performance: Challenges for the British Private Sector in a Dynamic Environment," Paper presented at the British Universities Industrial Relations Association (BUIRA) 59th Annual Conference, July.

Wood, S. J., and L. de Menezes (1998)."High Commitment Management in the UK: Evidence from the Workplace Industrial Relations Survey and Employers' Manpower and Skills Practices Survey," Human Relations 51 (4), 485 - 515.

Wood, S. J., L. M. de Menezes, and A. Lasaosa (2003). "Family-Friendly Management in Great Britain: Testing Various Perspectives," Industrial Relations 42 (2), 221 - 250.

Woodland, S., N. Simmonds, M. Thornby, R. Fitzgerald, and A. McGee (2003). The Second Work-Life Balance Study: Results from the Employer Survey-Main Report. DTI Employment Relations Research Series 22 (London. UK: DTI), Available online at: http://www.dti.gov.uk/er/emar/errs22MainReport.pdf (Accessed September 7, 2005).

Wooldridge, J. (2002). Econometric Analysis of Cross Section and Panel Data. Cambridge: MIT Press.

Yanadori, Y., and T. Kato (2009). "Work and Family Practices in Japanese Firms: Their Scope, Nature and Impact on Employee Turnover," International Journal of Human Resource Management 20 (2), 439 - 456.

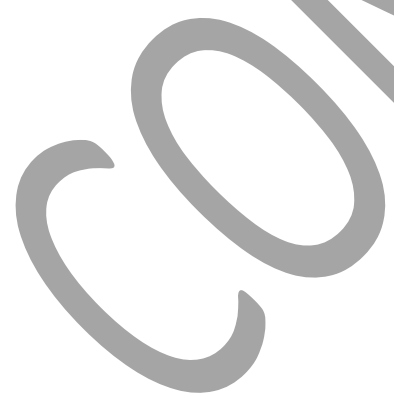


Table 1

Correlation Matrix and Summary Statistics ${ }^{\mathrm{a}}$

\begin{tabular}{|c|c|c|c|c|c|c|c|c|c|c|c|c|c|c|c|c|c|c|c|c|c|c|}
\hline & Mean S. D. & 1 & 2 & 3 & 4 & 5 & 6 & 7 & 8 & 9 & $\mathbf{1 0}$ & 11 & 12 & 13 & 14 & 15 & 16 & 17 & 18 & 19 & 20 & 21 \\
\hline \multicolumn{23}{|l|}{ SME Performance Indicators } \\
\hline 1. Redundancies $\wedge$ & $0.65 \quad 2.03$ & 1.00 & & & & & & & & & & & & & & & & & & & & \\
\hline 2. Absenteeism ${ }^{\wedge}$ & 5.5514 .68 & 0.03 & 1.00 & & & & & & & & & & & & & & & & & & & \\
\hline 3. Financial turnover ${ }^{\wedge}$ & $12.64 \quad 2.17$ & 0.28 & 0.10 & 1.00 & & & & & & & & & & & & & & & & & & \\
\hline \multicolumn{23}{|l|}{ Workplace Characteristics } \\
\hline 4. FirmSize ${ }^{\wedge}$ & 18.5934 .16 & 0.30 & 0.11 & 0.29 & 1.00 & & & & & & & & & & & & & & & & & \\
\hline 5. FamilyOwned & 0.630 .48 & -0.04 & 0.04 & -0.01 & -0.07 & 1.00 & & & & & & & & & & & & & & & & \\
\hline 6. Manufacturing & 0.210 .41 & -0.02 & -0.04 & 0.08 & -0.06 & 0.16 & 1.00 & & & & & & & & & & & & & & & \\
\hline 7. StaffFemaleShare ${ }^{\wedge}$ & $0.38 \quad 0.31$ & -0.13 & 0.14 & -0.02 & -0.09 & 0.00 & -0.24 & 1.00 & & & & & & & & & & & & & & \\
\hline 8. ManagerFemaleShare ${ }^{\wedge}$ & $0.33 \quad 0.35$ & -0.04 & 0.11 & -0.08 & 0.00 & 0.08 & -0.11 & 0.29 & 1.00 & & & & & & & & & & & & & \\
\hline 9. MarketCompetition & 0.510 .50 & 0.11 & -0.10 & -0.07 & 0.21 & -0.06 & -0.03 & -0.17 & -0.15 & 1.00 & & & & & & & & & & & & \\
\hline \multicolumn{23}{|l|}{ Workplace Flexibility Practices (WFPs) } \\
\hline \multicolumn{23}{|l|}{ Numerical flexibility } \\
\hline 10. Home_or_MobileWork & $0.44 \quad 0.50$ & -0.04 & 0.05 & -0.20 & -0.07 & -0.10 & -0.17 & 0.08 & O.1. & -0.03 & 1.00 & & & & & & & & & & & \\
\hline 11. FamilyFriendly & $0.41 \quad 0.49$ & 0.05 & -0.01 & 0.15 & 0.07 & -0.19 & -0.12 & 0.28 & 0.15 & -0.30 & 0.13 & 1.00 & & & & & & & & & & \\
\hline 12. Part-TimeWork & $0.37 \quad 0.49$ & 0.06 & 0.12 & -0.12 & 0.03 & 0.01 & -0.11 & 0.27 & 0.15 & -0.19 & 0.15 & 0.29 & 1.00 & & & & & & & & & \\
\hline 13. Flexitime & $0.25 \quad 0.44$ & -0.07 & 0.08 & 0.16 & 0.16 & -0.05 & -0.20 & 0.28 & 0.19 & -0.10 & 0.16 & 0.30 & 0.17 & 1.00 & & & & & & & & \\
\hline \multicolumn{23}{|l|}{ Functional flexibility } \\
\hline 14. Teams_or_JobAut_or_EI & $0.83 \quad 0.38$ & 0.13 & 0.13 & 0.10 & 0.11 & -0.03 & -0.18 & -0.01 & -0.06 & 0.10 & 0.06 & 0.22 & 0.18 & 0.18 & 1.00 & & & & & & & \\
\hline 15. Train_or_JobEnrichment & 0.710 .45 & 0.06 & -0.03 & 0.03 & 0.16 & 0.14 & -0.16 & 0.13 & 0.10 & 0.01 & -0.04 & 0.28 & 0.27 & 0.23 & 0.31 & 1.00 & & & & & & \\
\hline 16. JobSecurity & $0.70 \quad 0.46$ & 0.16 & -0.01 & 0.30 & 0.19 & 0.14 & 0.03 & 0.00 & -0.07 & 0.06 & -0.14 & 0.18 & 0.21 & 0.01 & 0.31 & 0.30 & 1.00 & & & & & \\
\hline 17. JobSharing & 0.120 .33 & -0.06 & -0.05 & 0.07 & 0.01 & -0.06 & 0.00 & -0.01 & 0.01 & -0.07 & -0.13 & -0.09 & 0.10 & 0.09 & 0.04 & 0.11 & 0.03 & 1.00 & & & & \\
\hline \multicolumn{23}{|l|}{ Cost flexibility } \\
\hline 18. MgtPayCut_or_PayFreeze_or_BonusCut & $0.54 \quad 0.50$ & 0.16 & 0.05 & 0.05 & 0.20 & -0.06 & -0.03 & -0.05 & -0.14 & 0.05 & 0.19 & 0.03 & 0.08 & -0.05 & 0.22 & 0.11 & 0.01 & 0.00 & 1.00 & & & \\
\hline 19. StaffPayFreeze & $0.30 \quad 0.46$ & 0.30 & 0.08 & 0.26 & 0.24 & -0.15 & 0.04 & -0.07 & -0.12 & -0.10 & 0.06 & 0.18 & 0.07 & 0.15 & 0.18 & 0.06 & 0.18 & -0.06 & 0.27 & 1.00 & & \\
\hline 20. IndivPerformanceRelPay & $0.19 \quad 0.39$ & 0.21 & 0.02 & 0.14 & 0.09 & 0.02 & -0.14 & -0.06 & -0.17 & 0.15 & 0.08 & 0.02 & 0.09 & 0.08 & 0.14 & 0.23 & 0.17 & 0.16 & 0.10 & 0.08 & 1.00 & \\
\hline 21. ProfitRelPay & $0.18 \quad 0.38$ & 0.03 & 0.01 & 0.22 & 0.07 & -0.02 & 0.05 & -0.19 & -0.18 & 0.05 & -0.12 & 0.01 & -0.23 & 0.10 & 0.10 & 0.12 & 0.05 & 0.21 & 0.22 & 0.03 & 0.29 & 1.00 \\
\hline
\end{tabular}


Table 2

Summary of Results: Relationships between Workplace Flexibility Practices (WFPs) and SME Performance Indicators ${ }^{\text {a }}$

\begin{tabular}{|c|c|c|c|c|c|c|c|}
\hline & 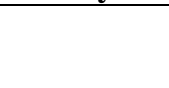 & \multicolumn{2}{|c|}{$\begin{array}{l}\text { SME Performance Indicator: } \\
\text { Redundancies }\end{array}$} & \multicolumn{2}{|c|}{$\begin{array}{c}\text { SME Performance Indicator: } \\
\text { Absenteeism }\end{array}$} & \multirow[t]{2}{*}{$\begin{array}{l}\text { SME Performance Indicator: } \\
\text { Financial Turnover }\end{array}$} & \multirow[b]{2}{*}{ Size $^{\text {d }}$} \\
\hline & & WFPs & Size $^{\text {b }}$ & WFPs & Size $^{c}$ & & \\
\hline \multirow{3}{*}{$\begin{array}{l}\text { Relationships of a } \\
\text { positive } \\
\text { connotation } \\
\text { between WFPs and } \\
\text { SME performance } \\
\text { indicators }\end{array}$} & $\begin{array}{l}\text { Numerical } \\
\text { WFPs }\end{array}$ & Flexitime & $0.5 * * *$ & $\begin{array}{l}\text { FamilyFriendly } \\
\text { Part-TimeWork }\end{array}$ & & & \\
\hline & $\begin{array}{l}\text { Functional } \\
\text { WFPs }\end{array}$ & JobSharing & $0.4 * *$ & $\begin{array}{l}\text { Train_or_JobEnrichment } \\
\text { JobSecurity } \\
\text { JobSharing }\end{array}$ & $\begin{array}{l}5.9 * * * \\
5.9 * * * \\
4.4 * * * \\
\end{array}$ & JobSecurity & $1.2 * *$ \\
\hline & $\begin{array}{l}\text { Cost } \\
\text { WFPs }\end{array}$ & ProfitRelatedPay & $2.2 * *$ & - & & $\begin{array}{l}\text { StaffPayFreeze } \\
\text { ProfitRelatedPay }\end{array}$ & $\begin{array}{l}0.8^{*} \\
1.8^{*}\end{array}$ \\
\hline \multirow{3}{*}{$\begin{array}{l}\text { Relationships of a } \\
\text { negative } \\
\text { connotation } \\
\text { between WFPs and } \\
\text { SME performance } \\
\text { indicators }\end{array}$} & $\begin{array}{l}\text { Numerical } \\
\text { WFPs }\end{array}$ & Part-TimeWork & $0.6^{*}$ & & $2.5^{* * * *}$ & $\begin{array}{l}\text { Home_or_MobileWork } \\
\text { Part-TimeWork }\end{array}$ & $\begin{array}{l}0.7^{*} \\
0.8^{*}\end{array}$ \\
\hline & $\begin{array}{l}\text { Functional } \\
\text { WFPs }\end{array}$ & JobSecurity & $2.0 * *$ & Teams_or_JobAut_or_EI & $3.8 * * *$ & - & \\
\hline & $\begin{array}{l}\text { Cost } \\
\text { WFPs }\end{array}$ & StaffPayFreeze & $0.8 * * *$ & StaffPayFreeze & $1.3 * *$ & MgtPayCut_or_PayFreeze_or_BonusCut & $0.9 * *$ \\
\hline
\end{tabular}

${ }^{\mathrm{a}}$ This table reports only the statistically significant relationships, based on marginal effects reported in Table 3 and Table 4 , and based on the coefficients reported in Table 5 . The statistical significance of the relationships is shown as follows: *** means a highly significant relationship ( $p$ value $<0.01)$; ** means a significant relationship $(p$ value $<0.05)$; and $*$ means a marginally significant relationship $(p$ value $<0.1) . N$ ranges from 101 to 135 across variables.

${ }^{b}$ The size of the WFPs-redundancies relationships relates to the annual estimated number of redundancies. For example, compared to SMEs without flexitime, SMEs implementing flexitime are likely to have an annual level of redundancies that is lower by 0.5 employees. Or, compared to SMEs not implementing part-time work, SMEs implementing part-time work are likely to have an annual level of redundancies that is higher by of 0.6 employees.

${ }^{\mathrm{c}}$ The size of the WFPs-absenteeism relationships relates to the annual estimated number of days of absence per employee. For example, compared to SMEs without family friendly practices, SMEs implementing family friendly practices are likely to have an annual level of absenteeism that is lower by 2.8 days per employee. Or, compared to SMEs not implementing staff pay freezes, SMEs implementing staff pay freezes are likely to have an annual level of absenteeism that is higher by of 1.3 days per employee.

${ }^{\mathrm{d}}$ The size of the relationships between WFPs and financial turnover relates to the annual estimated value of financial turnover. For example, compared to SMEs not offering employee job security, SMEs offering job security are likely to have an annual level of financial turnover that is higher by a factor of 1.2. Or, compared to SMEs not implementing pay cuts or pay freezes or bonus cuts for management, SMEs implementing some of these cost flexibility measures are likely to have an annual level of financial turnover that is lower by a factor of 0.9 . 
Table 3

Results of Zero-Inflated Poisson Regression: Workplace Flexibility Practices and Redundancies ${ }^{\mathrm{a}}$

\begin{tabular}{|c|c|c|c|c|c|c|c|c|c|c|c|c|c|}
\hline \multirow{2}{*}{\multicolumn{2}{|c|}{ Variable }} & \multicolumn{4}{|c|}{ Model 1} & \multicolumn{4}{|c|}{ Model 2} & \multicolumn{4}{|c|}{ Model 3} \\
\hline & & Coef. & Signif. & Dy/Dx & Signif. & Coef. & Signif. & Dy/Dx & Signif. & Coef. & Signif. & Dy/Dx & Signif. \\
\hline \multirow{7}{*}{ 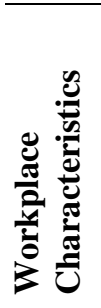 } & Count Data Models & & & & & & & & & & & & \\
\hline & FirmSize & 0.006 & $* * *$ & 0.013 & $* *$ & 0.003 & & 0.011 & & 0.010 & $* * *$ & 0.005 & $* *$ \\
\hline & FamilyOwned & -0.477 & & 0.072 & & -2.137 & $* * *$ & -0.634 & & 0.086 & & 0.086 & \\
\hline & Manufacturing & -0.374 & & -0.177 & & -1.022 & $* *$ & -0.477 & $*$ & -0.056 & & 0.023 & \\
\hline & StaffFemaleShare & -2.904 & $* * *$ & -0.697 & & -2.485 & $* * *$ & -0.923 & & -2.346 & $* *$ & -0.256 & \\
\hline & ManagerFemaleShare & 1.259 & & 0.034 & & 3.069 & $* * *$ & 0.847 & & -0.348 & & -0.260 & \\
\hline & MarketCompetition & -0.479 & & 0.290 & & -2.936 & $* * *$ & -0.657 & & -0.410 & & 0.214 & \\
\hline \multirow{5}{*}{ 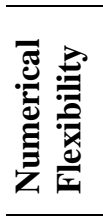 } & Home_or_MobileWork & 0.523 & & 0.265 & & & & & & & & & \\
\hline & FamilyFriendly & 0.291 & & 0.142 & & & & & & & & & \\
\hline & Part-TimeWork & 1.091 & $* *$ & 0.620 & $*$ & & & & & & & & \\
\hline & Flexitime & -1.217 & $* * *$ & -0.459 & $* * *$ & & & & & & & & \\
\hline & Constant & 1.319 & $* * *$ & & & & & & & & & & \\
\hline \multirow{5}{*}{ 预司 } & Teams_or_JobAut_or_EI & & & & & -3.080 & $* *$ & -7.530 & & & & & \\
\hline & Train_or_JobEnrichment & & & & & 0.116 & & 0.064 & & & & & \\
\hline & JobSecurity & & & & & 5.183 & $* * *$ & 2.015 & $* *$ & & & & \\
\hline & JobSharing & & & & & -1.075 & $*$ & -0.425 & $* *$ & & & & \\
\hline & Constant & & & & & 2.310 & $* *$ & & & & & & \\
\hline \multirow{13}{*}{ 范 } & MgtPayCut_or_PayFreeze_or_BonusCut & & & & & & & & & -0.701 & & -0.235 & \\
\hline & StaffPayFreeze & & & & & & & & & 1.687 & $* * *$ & 0.847 & $* * *$ \\
\hline & IndivPerformanceRelPay & & & & & & & & & 0.529 & & 0.199 & \\
\hline & ProfitRelatedPay & & & & & & & & & -0.965 & $*$ & -0.232 & $* *$ \\
\hline & Constant & & & & & & & & & 0.846 & & & \\
\hline & Inflate Equations & & & & & & & & & & & & \\
\hline & FirmSize & -0.028 & $*$ & & & -0.022 & $*$ & & & -0.011 & & & \\
\hline & FamilyOwned & -0.840 & & & & -1.529 & $*$ & & & -0.287 & & & \\
\hline & Manufacturing & 0.057 & & & & 0.091 & & & & -0.195 & & & \\
\hline & StaffFemaleShare & -1.941 & & & & -1.201 & & & & -2.332 & & & \\
\hline & ManagerFemaleShare & 1.605 & & & & 2.207 & $*$ & & & 0.713 & & & \\
\hline & MarketCompetition & -1.525 & $* *$ & & & -2.417 & $* * *$ & & & -1.726 & $*$ & & \\
\hline & Constant & 3.003 & $* * *$ & & & 3.179 & $* * *$ & & & 2.571 & $* * *$ & & \\
\hline
\end{tabular}

$p<0.05 * p<0.1 ;$ Dy/Dx, Marginal effects. Marginal effects are evaluated at the mean

Model 1: $N=111$, non-zero observations $=23$, zero observations $=88$, Voung test statistic $2.32 * * ;$ Model 2: $N=110$, non-zero observations $=21$, zero observations $=89$, Voung test statistic $2.52 * * * ;$ Model

3: $N=111$, non-zero observations $=22$, zero observations $=89$, Voung test statistic $1.98 * *$. 
Table 4

Results of Zero-Inflated Poisson Regression: Workplace Flexibility Practices and Absenteeism ${ }^{\text {a }}$

\begin{tabular}{|c|c|c|c|c|c|c|c|c|c|c|c|c|c|}
\hline & \multirow[b]{2}{*}{ Variable } & \multicolumn{4}{|c|}{ Model 4} & \multicolumn{4}{|c|}{ Model 5} & \multicolumn{4}{|c|}{ Model 6} \\
\hline & & Coef. & Signif. & Dy/Dx & Signif. & Coef. & Signif. & Dy/Dx & Signif. & Coef. & Signif. & Dy/Dx & Signif. \\
\hline \multirow{7}{*}{ 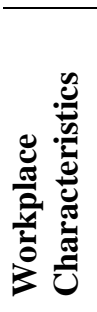 } & Count Data Models & & & & & & & & & & & & \\
\hline & FirmSize & 0.004 & $* * *$ & 0.093 & $* * *$ & 0.004 & $* * *$ & 0.089 & $* *$ & 0.002 & $* *$ & 0.096 & $* * *$ \\
\hline & FamilyOwned & 0.235 & $* *$ & 1.614 & $* *$ & 0.789 & $* * *$ & 4.589 & $* * *$ & 0.370 & $* * *$ & 2.239 & $* * *$ \\
\hline & Manufacturing & -0.188 & & -1.040 & & -0.263 & $*$ & -1.388 & $*$ & -0.261 & $*$ & -1.321 & \\
\hline & StaffFemaleShare & 0.570 & $* * *$ & 4.570 & $* * *$ & -0.020 & & 0.773 & & 0.006 & & 1.396 & \\
\hline & ManagerFemaleShare & 0.688 & $* * *$ & 3.449 & $* * *$ & 1.496 & $* * *$ & 8.551 & $* * *$ & 1.037 & $* * *$ & 5.546 & $* * *$ \\
\hline & MarketCompetition & -0.605 & $* * *$ & -3.744 & $* * *$ & -0.400 & $* * *$ & -2.507 & $* * *$ & -0.446 & $* * *$ & -2.778 & $* * *$ \\
\hline \multirow{5}{*}{ 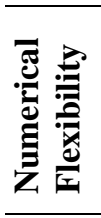 } & Home_or_MobileWork & 0.386 & $* * *$ & 2.489 & $* * *$ & & & & & & & & \\
\hline & FamilyFriendly & -0.467 & $* * *$ & -2.807 & $* * *$ & & & & & & & & \\
\hline & Part-TimeWork & -0.216 & $* *$ & -1.293 & $* *$ & & & & & & & & \\
\hline & Flexitime & 0.151 & & 0.964 & & & & & & & & & \\
\hline & Constant & 1.647 & $* * *$ & & & & & & & & & & \\
\hline \multirow{5}{*}{ 矛 } & Teams_or_JobAut_or_EI & & & & & 0.819 & $* * *$ & 3.834 & $* * *$ & & & & \\
\hline & Train_or_JobEnrichment & & & & & -0.785 & $* * *$ & -5.941 & $* * *$ & & & & \\
\hline & JobSecurity & & & & & -0.775 & $* * *$ & -5.931 & $* * *$ & & & & \\
\hline & JobSharing & & & & & -1.028 & $* * *$ & -4.443 & $* * *$ & & & & \\
\hline & Constant & & & & & 1.665 & $* * *$ & & & & & & \\
\hline \multirow{13}{*}{ 它 } & MgtPayCut_or_PayFreeze_or_BonusCut & & & & & & & & & -0.055 & & -0.338 & \\
\hline & StaffPayFreeze & & & & & & & & & 0.202 & $* *$ & 1.306 & $* *$ \\
\hline & IndivPerformanceRelPay & & & & & & & & & -0.010 & & -0.061 & \\
\hline & ProfitRelatedPay & & & & & & & & & -0.018 & & -0.109 & \\
\hline & Constant & & & & & & & & & 1.540 & $* * *$ & & \\
\hline & Inflate Equations & & & & & & & & & & & & \\
\hline & FirmSize & -0.178 & $* * *$ & & & -0.198 & $* * *$ & & & -0.171 & $* * *$ & & \\
\hline & FamilyOwned & -0.504 & & & & 0.024 & & & & -0.045 & & & \\
\hline & Manufacturing & -0.170 & & & & -0.424 & & & & -0.481 & & & \\
\hline & StaffFemaleShare & -2.761 & $* *$ & & & -2.747 & $* *$ & & & -2.871 & $* * *$ & & \\
\hline & ManagerFemaleShare & 2.071 & $* *$ & & & 1.904 & $* *$ & & & 1.830 & $* *$ & & \\
\hline & MarketCompetition & -0.082 & & & & 0.145 & & & & 0.016 & & & \\
\hline & Constant & 1.308 & $*$ & & & 1.230 & $*$ & & & 1.300 & $*$ & & \\
\hline
\end{tabular}

observations $=33$, Voung test statistic $2.20^{* *}$; 
Table 5

Results of Linear Regression (OLS): Workplace Flexibility Practices and Financial Turnover ${ }^{\mathrm{a}}$

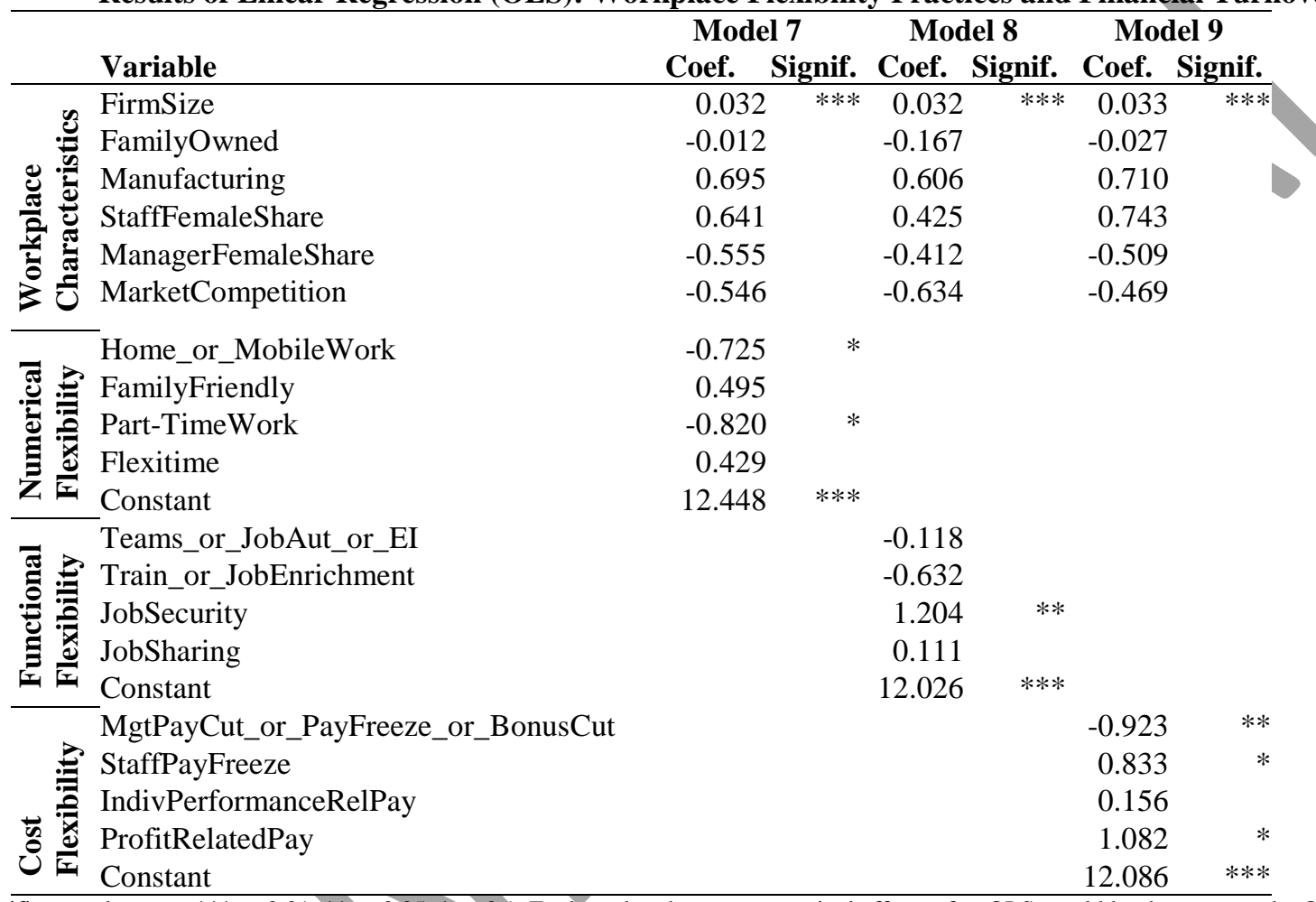

${ }^{a}$ Coef., Coefficient; Signif., Significance shown as *** $p<0.01, * * p<0.05, * p<0.1$ Evaluated at the mean, marginal effects after OLS would be the same as the OLS slope coefficients, so marginal effects do not need to be reported. Model 7: $N=106, R$ Squared $=0.34, F$ test statistic $=4.94 * * *$. Model $8: N=105, R$ Squared $=0.32, F$ test statistic $=4.43 * * *$. Model $9: N=106, R$ Squared $=0.34, F$ test statistic $=$ $4.85^{* *}$ 
Figure 1

Conceptual Model for Analysing the Relationship between Workplace Flexibility Practices (WFPs) and Firm Performance: Testing Nine Models

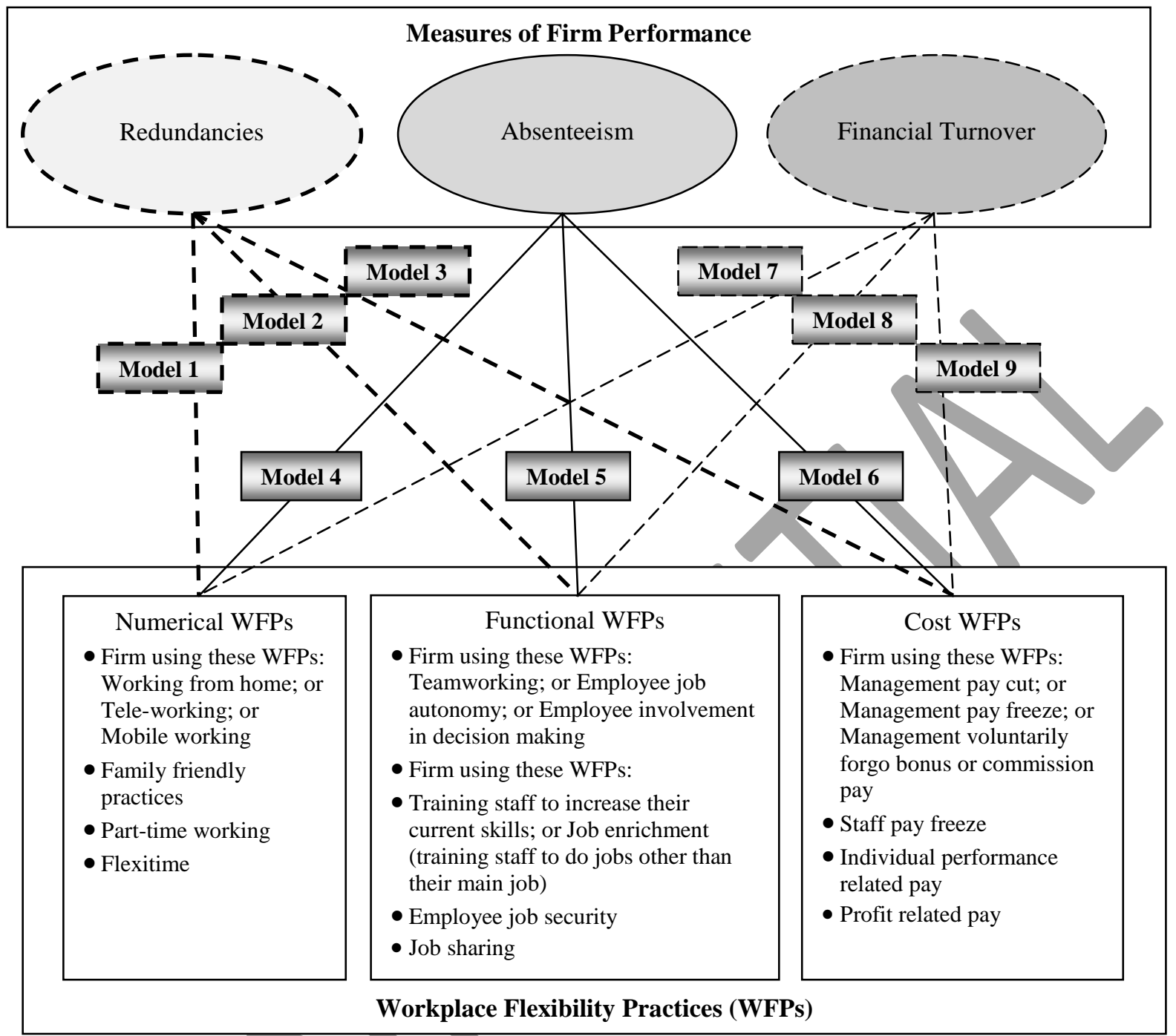




\section{Appendix 1}

\section{Description of Workplace Flexibility Practices Analysed}

The questionnaire asked Small and Medium Enterprises about their use of workplace flexibility practices in the context of the 2009 economic recession, specifically: "In response to recession in your organisation, please rate the use of these practices over the past 12 months?"

Workplace Flexibility Practices (WFPs):

Name of WFPs as Used in Analysis and Full Name of WFPs

\begin{tabular}{|c|c|c|}
\hline \multirow{4}{*}{ : } & $\begin{array}{l}\text { Home_or_MobileWork } \\
\text { Full name: Firm using these WFPs: } \\
\text { Working from home; or } \\
\text { Tele-working; or } \\
\text { Mobile working }\end{array}$ & $\begin{array}{l}\text { This set of WFPs combines working at home, with various forms of working } \\
\text { away from the main office, on a regular or intermittent basis. } \\
\text { An employee may be working from home occasionally, or for an agreed } \\
\text { number of days each week. It also relates to the use of telecommunications and } \\
\text { technology, such as Voice over IP (VoIP) and video-conferencing, to replace } \\
\text { work related travel and enable working from home. }\end{array}$ \\
\hline & $\begin{array}{l}\text { FamilyFriendly } \\
\text { Full Name: Family friendly practices }\end{array}$ & $\begin{array}{l}\text { These are practices designed to help employees balance work and family } \\
\text { roles. Examples include alternative work arrangements to make it easier for } \\
\text { parents to work at particular times in the year (e.g. school tem time) or to } \\
\text { change working times in view of child-care arrangements, or dependent care } \\
\text { support. }\end{array}$ \\
\hline & $\begin{array}{l}\text { Part-TimeWork } \\
\text { Full name: Part-tim }\end{array}$ & Part-time employees are those contracted to work less than full-time hours. \\
\hline & $\begin{array}{l}\text { Flexitime } \\
\text { Full name: Flexitime }\end{array}$ & $\begin{array}{l}\text { Workers have the freedom to work in any way they choose outside a set core } \\
\text { of hours determined by the employer. They may vary their start, finish and } \\
\text { break times each day, but sometimes within agreed limits. }\end{array}$ \\
\hline \multirow{4}{*}{ 常 } & $\begin{array}{l}\text { Teams_or_JobAut_or_EI } \\
\text { Full name: Firm using these WFPs: } \\
\text { Teamworking; or } \\
\text { Employee job autonomy; or } \\
\text { Employee involvement in decision } \\
\text { making }\end{array}$ & $\begin{array}{l}\text { This practice involves organising employees into teams based on a distinct } \\
\text { product, part of a process, or service. This may cut across existing functional } \\
\text { divides. Teams are sometimes given a high degree of responsibility and } \\
\text { expected to work with increased flexibility. } \\
\text { Job autonomy relates to the degree or level of freedom and discretion allowed } \\
\text { to an employee over his or her job. Via job autonomy, employees are allowed a } \\
\text { degree of choice over issues such as how their work is done, where their work is } \\
\text { done, the pace of their work, their tasks to be done, or a combination of these } \\
\text { issues. } \\
\text { Implementing employee involvement practices means creating an } \\
\text { environment in which employees have an impact on decisions and actions that } \\
\text { affect their jobs. }\end{array}$ \\
\hline & $\begin{array}{l}\text { Frain_or_JobEnrichment } \\
\text { Full name: Firm using these WFPs: } \\
\text { Training staff to increase their current } \\
\text { skills; or } \\
\text { Job enrichment (training staff to do jobs } \\
\text { other than their main job) }\end{array}$ & $\begin{array}{l}\text { Training programmes may be implemented to target the current range of skills } \\
\text { for the workforce and develop these skills. Or, training programmes may be } \\
\text { implemented to allow the workforce to expand their current range of skills and } \\
\text { include skills related to tasks other than their main tasks, thereby "enriching" } \\
\text { their jobs. }\end{array}$ \\
\hline & $\begin{array}{r}\text { JobSect } \\
\text { Full n }\end{array}$ & $\begin{array}{l}\text { Assurance that an employee has about the continuity of gainful employment } \\
\text { for his or her work life. Job security usually arises from the terms of the contract } \\
\text { of employment, collective bargaining agreements, or labour legislation that } \\
\text { prevents arbitrary termination, layoffs, and lockouts. It may also be affected by } \\
\text { general economic conditions. }\end{array}$ \\
\hline & Ful & $\begin{array}{l}\text { This is a work arrangement in which more than one employees share one job. } \\
\text { In effect, these employees work part-time, although their combined hours make } \\
\text { up the equivalent of a full-time job. So job sharing is a form of part-time } \\
\text { working where two (or occasionally more) people share the responsibility for a } \\
\text { full-time job. They share the pay and benefits in proportion to the hours each } \\
\text { works. Job sharers may work, for instance, split days, split weeks, or alternate } \\
\text { weeks }\end{array}$ \\
\hline \multirow{4}{*}{ 离 } & $\begin{array}{l}\text { MgtPayCut_or_PayFreeze_or_BonusCut } \\
\text { Full name: Firm using these WFPs: } \\
\text { Management pay cut; or Management } \\
\text { pay freeze; or } \\
\text { Management voluntarily forgo bonus or } \\
\text { commission pay }\end{array}$ & $\begin{array}{l}\text { Usually as part of a firm's cost-cutting efforts, management may see a } \\
\text { decrease in their usual wages, or have their pay kept constant (frozen) over a } \\
\text { period of time, or voluntarily agree to not take their bonus or commission pay }\end{array}$ \\
\hline & $\begin{array}{l}\text { StaffPayFreeze } \\
\text { Full name: Staff pay freeze } \\
\end{array}$ & $\begin{array}{l}\text { Staff pay is kept constant (frozen) over a period of time, usually as part of a } \\
\text { firm's cost-cutting efforts. }\end{array}$ \\
\hline & $\begin{array}{l}\text { IndivPerformanceRelPay } \\
\text { Full name: Individual performance related } \\
\text { pay }\end{array}$ & $\begin{array}{l}\text { Pay levels, bonus earnings or other financial rewards are based on an } \\
\text { assessment or appraisal of an individual employee's performance against } \\
\text { previously set objectives. }\end{array}$ \\
\hline & $\begin{array}{l}\text { ProfitRelPay } \\
\text { Full name: Profit related pay }\end{array}$ & $\begin{array}{l}\text { The amount of pay or other financial rewards received are directly linked to } \\
\text { the firm's profitability. }\end{array}$ \\
\hline
\end{tabular}




\section{Appendix 2 \\ Technical Notes on Estimation Methods}

Via zero-inflated Poisson regressions it is assumed in this paper that there are two simultaneous processes generating the zero level of redundancies and absenteeism. On the one hand, some SMEs will not lay off any employees because there the managers follow an absolute rule of keeping their staff levels constant. With regard to absenteeism, some employees may have an absolute rule of no voluntary absenteeism. On the other hand, other SMEs may choose to not lay off permanent employees in the period observed. Similarly, some other employees may chose voluntarily during the observed period to be or not to be absent. The separate processes influencing the zero outcome are both influencing the outcome $Y=0$, so the zero-inflated count data models allows to account for both processes via an inflation equation. So, in a zero-inflated model, the outcome is determined by the absolute rule of never laying off staff or no involuntary absenteeism with probability $p_{i}$, as well as the count data process with probability $1-p_{i}$, whereby:

$\operatorname{Prob}\left[\mathrm{Y}_{i}=0\right]=p_{i}+\left(1-p_{i}\right) R_{i}(0)$

$\operatorname{Prob}\left[\mathrm{Y}_{i}=j>0\right]=\left(1-p_{i}\right) R_{i}(j)$

where $R_{i}(\cdot)$ is the count data model probability. The ancillary state probability, $p_{i}$, can be estimated either via a logit or a probit model. The count data model, "inflate equations" containing the assumed factors that may determine whether the observed count is zero, and the marginal effects are reported in Table 3, respectively Table 4. In this paper, the inflate equations have been estimated by logit, and they assume that the determinants of excess zero counts for Redundancies and Absenteeism are the set of six workplace characteristics variables.

For further information on the method of zero-inflated Poisson regressions, see Vuong (1989), Greene (1994), Long (1997) or Wooldridge (2002).

A further indication that zero-inflated Poisson models fitted the data best comes from the observation that both dependent variables Redundancies and Absenteeism are over-dispersed, meaning that their standard deviation is higher than their mean. According to Long (1997) and Cameron and Trivedi (1998) this result should indicate to a researcher that it is not feasible to use a simple Poisson model in which the mean and standard deviation are constrained to be equal. Zero-inflated Poisson models have already been used in the literature to model absenteeism, for example in Frick and Malo (2008).

Following the work reported by Yanadori and Kato (2009), models were estimated initially separately with each WFP's association with the dependent variable being observed. Yanadori and Kato (2009) concentrated only on four WFPs: flexitime, longer maternity leave, longer child care leave and longer nursing care leave. In contrast, this research reports results for more than 12 WFPs. Therefore, due to space limitation, models where independent variables are entered one at a time are discussed but not reported; instead only the full model specifications are shown in Tables 3, 4 and 5.

Alternative estimations, for instance using a probit model on dependent variables generated as dummies for non-zero values, have given similar results. Furthermore, numerous estimations with slightly modified sets of workplace characteristics and / or selection of independent variables have been trialled, and alongside with postestimation tests - for the dependent variable Financial Turnover too - they indicate that the research results presented here are consistent and robust.

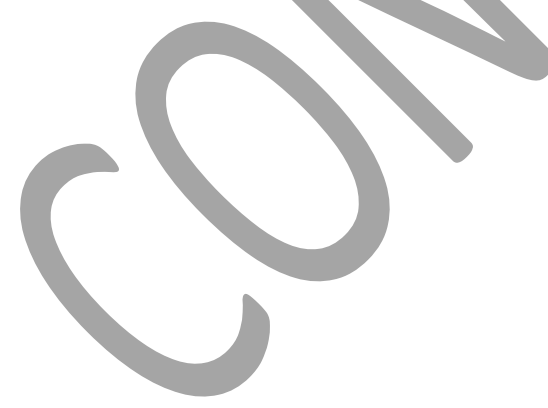

